Tér és Társadalom 11. évf. 1997/1. 73-108. p.

Tér és Társadalom

1997 1: $73-108$

\title{
ÉSZAKNYUGAT-DUNÁNTÚL GAZDASÁGI ÉS IPARI SZERKEZETÉNEK ÁTALAKULÁSA
}

\author{
(Transition of the Economic and Industrial Structure of Northwest \\ Transdanubia)
}

\section{MÁTHÉ MÁRIA}

Az elmúlt mintegy 30-40 év folyamán a magyar iparra a tervutasításos gazdálkodási rendszer túlzott mértékủ centralizált irányítása és néhány iparosításra kijelölt vidéki központ túlzott koncentrációja nyomta rá bélyegét. Annak ellenére, hogy az észak-dunántúli térség hagyományosan magasabb fokú ipari tradíciókkal rendelkezett, mint az ország más térségei (Budapest kivételével), hasonló ipari folyamatok játszódtak le, mint másutt. Ez a térség mindig meghatározó szerepet játszott az ország gazdasági életében, amit számos tényezö (történelmi gyökerek, viszonylag jó közlekedés-földrajzi fekvés, szakképzett és bőséges munkaerő, a nyugat-európai piacok közelsége, innováció-hordozó intézmények jelenléte, jó kooperációs kapcsolatok stb.) is segített.

Az 1980-as évek közepén egyértelmüvé vált, hogy a magyar gazdaság felemelkedésében az iparnak jelentós szerepe lesz, azonban ahhoz hogy az ipar a gazdaság motorja lehessen, alapvető szerkezeti átalakítást kell végrehajtani, melynek folyamatában erős orientációt a fejlett nyugati piacnak való megfelelés, az export fogja nyújtani (Török 1994).

A szerkezet-átalakítás egyúttal szervezeti átalakulásokat is maga után vont, ezért a szervezeti változások magukkal hozták az egyoldalú és szinte teljes körủ szocialista állami tulajdon felbontását, a dömping-privatizációs folyamatot (kb. 1987napjainkig (1996) is tart), valamint mindezek eredményeként egy átgondolt iparpolitika és stratégia kidolgozásának igényét - de nemcsak a központ szintjén mely a korábbi évtizedek által kialakított ipari körzetek mára depressziós térségekké vált ipari körzeteinek gazdasági szerkezetét is átalakítja. Az átalakítások végcélja a föként privátszektoron alapuló, kis és közepes (lokális, regionális és nemzetgazdasági szintű), valamint nagy (nemzet- és világgazdasági szintủ) vállalkozásokon felépülő piacgazdaság ${ }^{1}$ kialakítása.

Az átalakító folyamat során a gazdaságpolitika élni kívánt és kíván mind a közvetett, mind az aktív területi politika eszközeivel. (Barta 1991) Az előbbi keretében az indikatív tervezés módszerével feltárja az adott térség adottságait, erőforrásait, gyenge és erös pontjait, melyeket optimálisan hasznosítani igyekszik, a depressziós térségekben pedig effektív válságmenedzselést végez. Mindkét módszer során felhasználja:

- az elérhető támogatási formákat (elkülönített állami pénzalapok, adókedvezmények, MVA-beli kedvezményes hitelek, kamattámogatások, kockázati tőkefinanszírozási módok, Phare és OECD támogatások), 
- a szerkezet átalakítást, a fejlöđést segitö intézmények telepitését (inkubátorházak, ipari parkok, innovációs központok, különleges gazdasági, vállalkozói övezetek, vámszabad-területek, logisztikai központok),

- a lokális, a helyi hatalom szervezö, koordináló tevékenységét, az önkormányzatok lojalitását. (helyi adó kedvezmények, területbiztosítás, lokális gazdaságfejlesztési stratégia, iparfejlesztési koncepció stb.)

$\mathrm{Az}$ átalakulási folyamatokban a helyi önkormányzatok közellátási feladataikat tekintve hosszútávon is érdekeltek ${ }^{2}$, annak ellenére, hogy központi pénzügyi szabályozásuk rỏvid távon ellentétbe állithatja őket $(\mathrm{pl}$. az intézmény múködtetési központi normatívák alapján igényelt állami támogatás csökkentése miatt az önkormányzatok a bérleti dijak és helyi adók növelésében érdekeltek) a vállalkozások letelepítését támogató tevékenységükkel. (Mảthé 1993)

\section{Az ipar átalakulását, változásait tükrözö tényezők Észak-Dunántúlon}

Az ipari átalakulást, szerkezeti változást alapvetően azon tényezök alapján vizsgálom, melyekböl következtetni lehet arra, mely ágazatok bizonyultak az adott térség tágan értelmezett kultúrájában (városi környezet, a vállalatok egymás közötti munkamegosztása, speciális képességek felhalmozódása, innováció terjedése, társadalmi szerkezete, politikai szubkultúrája és történelmi öröksége) életképesnek bizonyulnak (Zeitlin 1994).

\subsection{A térség gazdasági és ipari foglalkoztatottjai szerkezetének változása 1985-1994 között}

A térségben foglalkoztatottak szerkezetének változását az egyes gazdasági ágakban az 1. táblázat mutatja. Az országos tendenciák jól felismerhetők ÉszakDunántúl egyes megyéiben és országosan is, a mintegy tízéves terminusban csökkenő tendenciájú a mezögazdaság és az ipar részaránya a gazdaság egészében, azonban ez a csökkenés, vagy helyesebben átrendeződés egyúttal a tercier szektor részarányának növekedésével járt. A foglalkoztatott aktív keresök száma (2. táblázat) a térség vállalatainál nagyobb mértékben csökkent, mint az országos vidéki átlag, a térségen belül a legnagyobb mérték Vas, Zala és Györ-MosonSopron megyét jellemezte.

Veszprém, Fejér és Komárom-Esztergom megye iparának létszámcsökkenése alatta maradt az országos vidéki átlag ütemének, az időszak első felében. Ebben szerepet játszott a megyék nagy foglalkoztatóinak (bányák, erőmủvek) állami tulajdonban tartása, mintegy védelme a megszüntetésǘk miatti gyors létszámleépitéssel járó sokkhatástól. Az idöszak második felében azonban ezekben a megyékben is felgyorsultak az egyes szektorok közötti átalakulási folyamatok.

Az ipari aktív keresők száma a legkevésbé az északnyugat dunántúli térségben csökkent, jelentősebb mértékben Veszprém megyében. Párhuzamosan a szolgáltatói szektor részaránya növekedett. Hasonló tendenciájában Fejér, Komárom-Esztergom megye szerkezeti arányainak (mind a mezögazdaság, mind az ipar ágazatai csökkentek), illetöleg az ipari aktiv keresők számának változásai. Győr-Moson- 
Sopron, Vas és Zala megyékben az átalakulási folyamatok, a szektorok egymás kőzötti átrendeződése nagyobb mértékủnek látszik a mezőgazdasági ágazatban, mint az ipari ágazatban.

\section{TÁBLÁZAT}

A foglalkoztatott aktiv keresők a fóbb gazdasági ágak szerint (\%) Active earners employed by main economic sectors (in per cent)

\begin{tabular}{|l|r|r|r|r|r|r|r|r|r|}
\hline \multicolumn{1}{|c|}{ Megye } & \multicolumn{3}{|c|}{ Mezőgazdaság } & \multicolumn{3}{c|}{ Ipart ép. ipar } & \multicolumn{3}{c|}{ Szolgáltatás } \\
\hline & 1984 & 1990 & 1995 & 1984 & 1990 & 1995 & 1984 & 1990 & 1995 \\
\hline Györ-M-S. & 18,2 & 14,7 & 9,0 & 42,9 & 40,8 & 37,7 & 38,9 & 44,5 & 53,3 \\
\hline Vas & 18,3 & 18,5 & 9,0 & 38,2 & 36,3 & 39,6 & 42,7 & 45,2 & 51,4 \\
\hline Veszprém & 15,7 & 15,1 & 7,1 & 47,6 & 41,3 & 40,4 & 36,7 & 43,6 & 52,5 \\
\hline Zala & 20,1 & 16,9 & 8,0 & 39,6 & 39,7 & 41,6 & 40,3 & 43,4 & 50,4 \\
\hline ÉNY-Dunántúl & 17,9 & 16,1 & 8,3 & 42,6 & 39,8 & 39,7 & 39,5 & 44,1 & 52,0 \\
\hline Fejér & 20,2 & 15,0 & 11,8 & 45,3 & 46,1 & 37,3 & 34,5 & 38,9 & 50,9 \\
\hline Kom.-Eszt. & 15,9 & 14,4 & 7,4 & 49,7 & 46,0 & 38,9 & 34,4 & 39,6 & 53,7 \\
\hline É-Dunántúl & 18,1 & 15,6 & 8,8 & 44,2 & 42,0 & 39,1 & 37,7 & 42,4 & 52,1 \\
\hline Vidék összesen & 22,0 & 18,5 & 10,2 & 39,8 & 38,6 & 35,1 & 38,2 & 42,9 & 54,7 \\
\hline Budapest & 4,9 & 3,1 & 1,0 & 41,3 & 36,3 & 25,9 & 53,8 & 60,6 & 73,1 \\
\hline $\begin{array}{l}\text { Ország } \\
\text { ószzesen }\end{array}$ & 18,6 & 15,4 & 8,1 & 40,1 & 38,1 & 33,1 & 41,3 & 46,5 & 58,8 \\
\hline
\end{tabular}

Forrás: KSH 1984. évi mikrocenzus, 1990. évi népszámlálás, 1995. évi munkaerö-felvétel

\section{TÁBLÁZAT}

A foglalkoztatott aktív keresók számának alakulása az iparban 1984-1995 (ezer fó)

Number of active earners employed in industry, 1984-1995 (thousand people)

\begin{tabular}{|c|c|c|c|c|c|}
\hline \multirow[t]{2}{*}{ Megye } & \multicolumn{3}{|c|}{ Ipari létszám (fö) } & \multirow{2}{*}{$\begin{array}{c}1995 \text { az } 1984 . \\
\text { év \%-ában }\end{array}$} & \multirow{2}{*}{$\begin{array}{l}\text { vidéki átlagtól való } \\
\text { eltérés (\% pont) }\end{array}$} \\
\hline & 1984 & 1990 & 1995 & & \\
\hline Györ-M-S & 85 & 78 & 63 & 74,1 & $+11,2$ \\
\hline Vas & 50 & 45 & 44 & 88,0 & $+25,1$ \\
\hline Veszprém & 88 & 71 & 57 & 64,8 & $+1,9$ \\
\hline Zala & 57 & 54 & 47 & 82,5 & $+19,6$ \\
\hline ÉNY-Dunántúl & 280 & 248 & 211 & 75,4 & $+12,5$ \\
\hline Fejér & 92 & 89 & 57 & 62,0 & $-0,9$ \\
\hline Kom.-Esztergom & 75 & 64 & 42 & 56,0 & $-6,9$ \\
\hline É-Dunántúl & 447 & 401 & 370 & 69,4 & $+6,5$ \\
\hline Vidék összesen & 1573 & 1392 & 990 & 62,9 & 0 \\
\hline Budapest & 400 & 333 & 208 & 52,0 & $-10,9$ \\
\hline Ország összesen & 1973 & 1725 & 1198 & 60,7 & $-2,2$ \\
\hline
\end{tabular}

Forrás: KSH 1984. évi mikrocenzus, 1990. évi népszámlálás, 1995. évi munkaerő-felvétel 

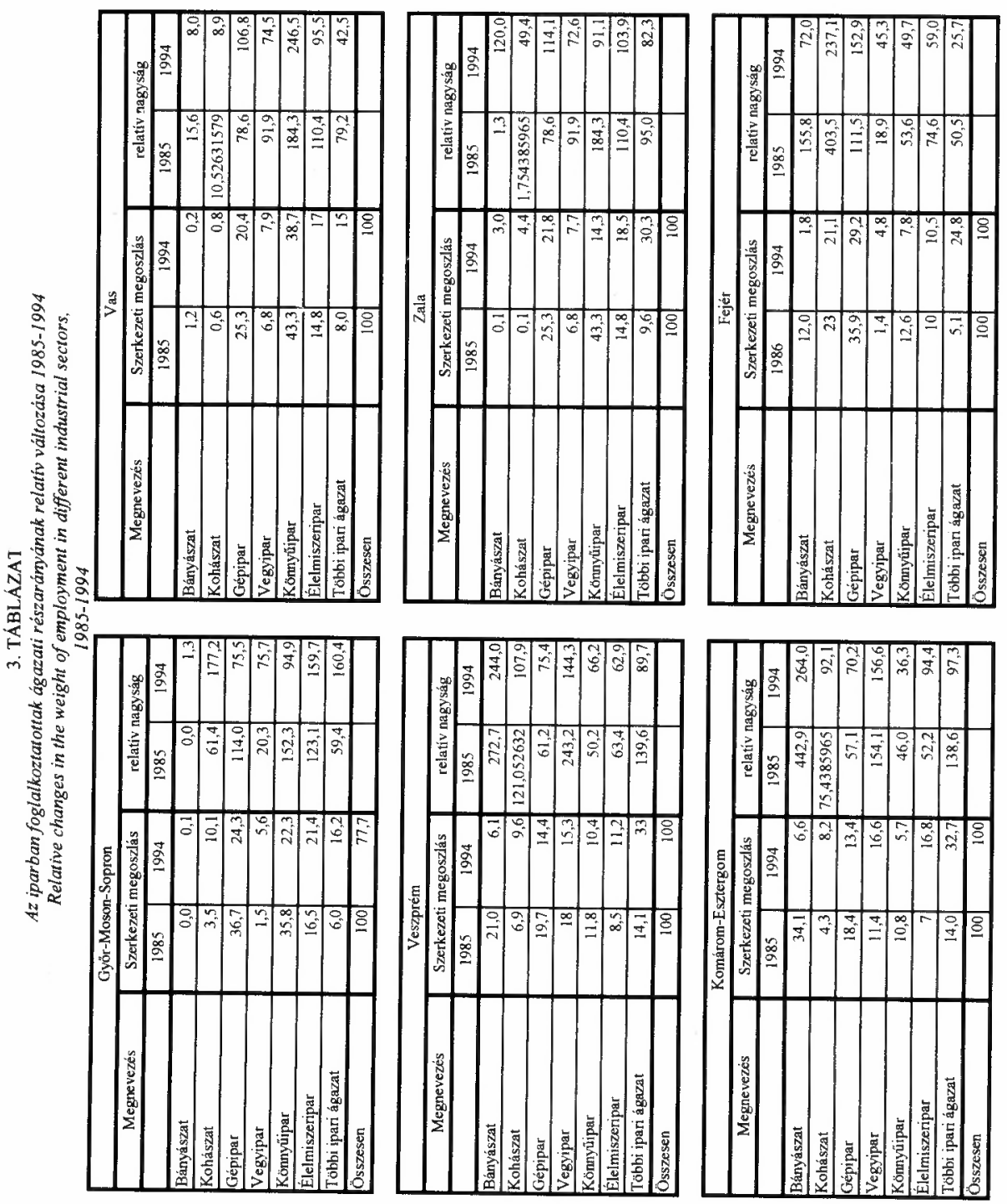


\section{Máthé Mária :}

Északnyugat-Dunántúl gazdasági és ipari szerkezetének átalakulása

Tér és Társadalom 11. évf. 1997/1. 73-108. p.

Az Északnyugat-Dunántúl ...

\section{TÁBLÁZAT}

A válság ágakban foglalkoztatottak arányainak változásai (\%)

Changes in the weight of employment in different crisis sectors (in per cent)

\begin{tabular}{|l|r|r|r|r|r|r|r|r|r|r|r|r|}
\hline \multicolumn{1}{|c|}{ Megye } & \multicolumn{3}{|c|}{ Ipar osszesen } & \multicolumn{3}{c|}{ Bányászat } & \multicolumn{3}{c|}{ Kohászat } & \multicolumn{3}{c|}{ Textilipar } \\
\hline & 1985 & 1990 & 1994 & 1985 & 1990 & 1994 & 1985 & 1990 & 1994 & 1985 & 1990 & 1994 \\
\hline Gy-M-S & 4,6 & 4,7 & 5,6 & 0,0 & 0,0 & 0,1 & 2,8 & 3,5 & 6,7 & 17,1 & 18,4 & 7,9 \\
\hline Vas & 2,6 & 2,8 & 3,8 & 0,0 & 0,0 & 0,3 & 0,0 & 0,0 & 0,4 & 7,1 & 7,9 & 9,4 \\
\hline Veszzrém & 4,4 & 4,5 & 4,6 & 11,9 & 14,0 & 11,2 & 5,3 & 6,8 & 5,0 & 1,9 & 2,5 & 3,1 \\
\hline Zala & 2,9 & 3,1 & 3,8 & 3,4 & 4,3 & 4,5 & 0,0 & 0,0 & 1,9 & 1,2 & 0,9 & 3,5 \\
\hline $\begin{array}{l}\text { ÉNY- } \\
\text { Dunántúl }\end{array}$ & 14,5 & 15,1 & 17,8 & 15,3 & 18,3 & 16,1 & 8,1 & 10,3 & 14,0 & 27,3 & 29,7 & 23,9 \\
\hline Fejér & 4,8 & 5,0 & 5,6 & 7,5 & 8,3 & 4,0 & 19,7 & 23,9 & 13,3 & 1,7 & 1,9 & 2,8 \\
\hline Kom,-Eszt. & 4,0 & 3,6 & 3,7 & 17,6 & 14,2 & 9,8 & 3,0 & 3,8 & 3,5 & 2,2 & 2,2 & 1,4 \\
\hline É-Dunántúl & 23,3 & 23,7 & 27,1 & 40,4 & 40,8 & 29,9 & 30,8 & 38,0 & 30,8 & 31,2 & 33,8 & 28,1 \\
\hline Vidék & 77,2 & 78,3 & 82,4 & 96,3 & 97,1 & 93,7 & 84,3 & 82,9 & 82,2 & 75,0 & 76,2 & 89,2 \\
\hline Bp. & 22,8 & 21,7 & 17,6 & 3,7 & 2,9 & 6,3 & 15,7 & 17,1 & 17,8 & 25,0 & 23,8 & 10,8 \\
\hline Ország & 100,0 & 100,0 & 100,0 & 100,0 & 100,0 & 100,0 & 100,0 & 100,0 & 100,0 & 100,0 & 100,0 & 100,0 \\
\hline
\end{tabular}

Forrás: KSH Területi statisztikai évkönyvek

Az ipar alágazatai részarányainak, tehát struktúrájának változását mutatja a 3. és a 4. táblázat, a 3. táblázatban a relatív nagyságok ${ }^{3}$ jól tükrözik az egyes megyék folyamatait, a 4. táblázat a válságágazatok változását jelzi.

Györ-Moson-Sopron megye iparában jelentösen meghaladja az országos vidéki átlagot a kohászat, az élelmiszeripar és a szolgáltató ipar részarányának növekedése. Érdekessége az iparszerkezetnek az, hogy a korábbi könnyúipari és gépipari súly veszitett jelentőségéböl.

Vas megyében a gépipar és a könnyüipar vált nagyobb súlyúvá, míg az élelmiszeripar súlya csökkent.

Veszprém megyében a bányászat szerepe alig csökkent, súlya jelentỏs, ugyanúgy a kohászat és a vegyipar is hangsúlyos. Csökkent a szolgáltató ipar súlya.

Zala megyében a gépipar és az élelmiszeripar vált az átalakulási folyamatok eredményeként jelentősebbé, de növekszik a bányászat és a kohászat mind részarányában, mind súlyában. Csökkent a korábban hangsúlyos könnyüỉpar.

Komárom-Esztergom megyében megnőtt a vegyipar, a kohászat szerepe, és szinte alig változott a bányászat súlya a megye iparában. Ezt az okozza, hogy az ország gazdasági szerkezetében jelentősen csökkent a bányászat részaránya más megyéknek köszönhetően.

Fejér megyében nagymértékben veszitett súlyából a bányászat és a kohászat, kismértékben a könnyü- és az élelmiszeripar. Jelentősebb növekedést mutat a gépipar és a vegyipar.

A hangsúlyos iparágak várhatóan a következő években kiemelkedő szerepet játszanak az egyes megyék és a térség átrendezödött gazdaságának egészében. 


\subsection{A bruttó hazai termék (GDP)}

A GDP értéke felvilágositást ad az egyes megyék jövedelemtermelö képességéröl (5. táblázat).

\section{TÁBLÁZAT}

A GDP ágazati szerkezete a térségben, 1994

The sectoral structure of GDP in the region, 1994

\begin{tabular}{|l|c|c|c|c|c|}
\hline \multicolumn{1}{|c|}{ Megye } & $\begin{array}{c}\text { GDP } \\
\text { (Mrd Ft) }\end{array}$ & \multicolumn{3}{c|}{ Szektorok közötti megoszlása (\%) } & $\begin{array}{c}1 \text { före jutó GDP } \\
\text { (E Ft) }\end{array}$ \\
\hline & & Mezögazdaság & Ipar+építöipar & Szolgáltatások & \\
\hline Györ-M.-S. & 191,3 & 11,2 & 35,4 & 53,4 & 449,0 \\
\hline Vas & 122,0 & 10,5 & 41,0 & 48,5 & 447,0 \\
\hline Veszprém & 126,6 & 6,6 & 35,6 & 57,8 & 335,0 \\
\hline Zala & 121,5 & 8,6 & 42,6 & 48,8 & 403,0 \\
\hline ÉNY-Dunántúl & 561,4 & 9,2 & 38,7 & 52,1 & 408,5 \\
\hline Fejér & 173,6 & 9,0 & 41,1 & 49,9 & 409,0 \\
\hline Kom.-Esztergom & 106,2 & 7,2 & 44,1 & 48,7 & 340,0 \\
\hline É-Dunántúl & 841,2 & 8,9 & 40,0 & 51,1 & 397,2 \\
\hline Vidék összesen & 2860,1 & 10,0 & 34,8 & 55,2 & 351,2 \\
\hline Budapest & 1504,7 & 0,7 & 22,2 & 77,1 & 767,0 \\
\hline Ország összesen & 4364,8 & 6,7 & 30,5 & 62,8 & 425,0 \\
\hline
\end{tabular}

Forrás: KSH feldolgozás

Északnyugat Dunántúlon a bruttó hazai termék (GDP) egy före jutó értéke GyőrMoson-Sopron és Vas megyében a legmagasabb (Budapest után), melynek létrehozásában a mezőgazdaság ágazatának is nagy szerep jutott, hiszen a másik két megyében a mezögazdaság kisebb súlyát nem ellensúlyozza a szolgáltatói szektor kibocsátásának viszonylag magasabb súlya. Az ipar modernizációs és gazdálkodási problémáit, az átalakulás elhúzódását a viszonylag alacsonyabb GDP érték is jelzi a két megyében.

\subsection{A munkanélküliség változása}

$\mathrm{Az}$ ipar átstrukturálódási folyamatának a szocialista ipartól idegen munkanélküliségi ráta (6. táblázat) fontos jelzöje. Komárom-Esztergom megyét kivéve - itt az ipar átalakulási folyamata idöben késỏbb kezdődött el éppen az állami szerepvállalásból adódóan - valamennyi megye rátája lassan csőkken ${ }^{4}$.

A térség rátáinak mértéke kisebb az országos átlaghoz képest és a fövárosi rátához képest is. Ez ugyanazt jelenti egyrészt, hogy az átalakulási folyamatok más térségekben késöbb indultak el, másrészt jelenti azt is, hogy más megyékben olyan térségek találhatók (rurális, elmaradott, depressziós), ahol tartósnak bizonyul a munkanélkuliség mert más súlyos gazdasági és társadalmi problémákhoz társul.

Napjainkra már egy másfajta - tehát már nem az átalakításból adódó létszámleépitésekkel - munkanélkülivé válási lehetöséggel kell szembenézni, nevezetesen a termelékenységnövekedés munkaerő kiváltó hatásával. 
A bécsi WHW Gazdaságkutató Intézet vizsgálódásai szerint (Kisalföld, 1996. április 16.) 1995 végén a magyar gépiparban a foglalkoztatottak $40 \%$-a külföldi érdekeltségü vállalatoknál dolgozik, melyekben az egy före jutó termelési érték átlagosan 52 millió Ft volt, míg a magyar cégeknél csak 30 millió Ft $(60 \%)$. Ugyanakkor a külföldi tulajdonosú cégeknél fizetett munkabérek átlagosan 11\%-kal magasabbak a magyar tulajdonosú cégek munkabéreinek. A külföldi érdekeltségü cégek a magyar gépipari áruforgalom 30\%-át, exportjának mintegy felét bonyolították le. A termelékenységnövekedés miatt viszont a külföldi beruházók az alkalmazottak felét elbocsátották.

\section{TÁBLÁZAT}

A munkanélküliségi ráta* alakulása

Development of the unemployment rate

\begin{tabular}{|l|r|r|r|r|r|}
\hline \multicolumn{1}{|c|}{ Megye } & 1992 & 1993 & 1994 & 1995 & 1996. dec. \\
\hline & \multicolumn{5}{|c|}{ S Z E P T E M B E R* } \\
\hline Györ-Moson-Sopron & 7,6 & 7,9 & 7,3 & 6,5 & 6,7 \\
\hline Vas & 8,0 & 8,8 & 7,7 & 6,8 & 6,8 \\
\hline Veszprém & 10,5 & 11,2 & 10,2 & 9,3 & 9,4 \\
\hline Zala & 8,6 & 10,0 & 9,5 & 9,1 & 9,2 \\
\hline ÉNY-Dunántúl & 9,5 & 10,8 & 9,7 & 8,7 & 8,0 \\
\hline Fejér & 9,9 & 12,6 & 9,9 & 10,0 & 9,0 \\
\hline Komárom-Esztergom & 13,3 & 13,4 & 12,2 & 10,7 & 11,5 \\
\hline É-Dunániúl & 10,6 & 12,2 & 10,3 & 9,9 & 8,8 \\
\hline Vidék összesen & 12,1 & 14,6 & 12,8 & 19,6 & 11,4 \\
\hline Budapest & 6,8 & 6,5 & 5,9 & 5,9 & 5,0 \\
\hline Ország összesen & 9,9 & 12,1 & 10,9 & 10,3 & 10,5 \\
\hline
\end{tabular}

* az elözö év I.l-i gazdaságilag aktiv népességéhez viszonyitva

Forrás: KSH Területi statisztikai évkönyvek, valamint PM Tájékoztató a gazdasági folyamatokról. Bp., 1996/11-12. sz.

\subsection{Ipari termelés és az exportarányok változása}

$\mathrm{Az}$ északnyugat-dunántúli régió gazdasági szerkezetének átalakulásában a külgazdasági orientációnak nagy a szerepe (7. táblázat), mert:

- a régió gazdaságának exportképessége kedvező, 1993-ban az ország ipari exportjának $27,2 \%$-át a térség hat megyéje adta, mely a vidéki exportjának több, mint egyharmadát teszi ki,

- a kedvező exportorientáció azonban ágazati egyenetlenséggel párosul, a térség vezetỏ ágazata a nehézipar (66\%). (8. táblázat)

- a jövöben a nemzetközi integrációban való részvételt kedvezöen befolyásolhatja a térség megyéinek közremüködése a közép-európai területi együttmüködésben. Az Alpok-Adria Munkaközösségben és a Duna Menti Tartományok Munkaközösségében felhalmozódott tapasztalatok - életképes programokkal párosulva - jó feltételei lehetnek e térség európai integrálódásának. A határmenti kooperációk fejlödésével számolni lehet a jövőben is. Kedvezönek minősithető az is, hogy a térség megyéi aktív kezdeményezői szerepet játszanak az Európai Régiók Gyülésében, eredményesen vesznek részt az Európai Közősség Ouverture pályázatain, 
külföldi szakéretők dolgozták ki a vállalkozásfejlesztési programokat, valamint a térség számtalan települése rendelkezik nyugat-európai kapcsolatokkal (pl. jól müködő testvérvárosi kapcsolatokkal, (Enyedi 1995).

- a humán infrastruktúra sok eleme alkalmas a külgazdaságbarát üzleti légkör fejlesztésére, de a régió felsőoktatási intézményeinek a nemzetközi együttmúkoödés terén még sok teendője van,

- a nemzetközi gazdasági kapcsolatok fejlesztését szolgáló piaci intézményrendszer csírái megtalálhatók a régió megyéiben. Kiépülöben vannak azok a szervezetek, amelyek a jövöben fontos szervezö és közvetitő szerepet játszhatnak a külkapcsolatok és az iparfejlesztés alakításában, így a kamarai hálózatok, valamint a különféle külkereskedelmi (értékesitỏ, marketing, piackutató, szállítmányozó) vállalkozások. (Horváth 1995)

\section{TÁBLÁZAT}

Az ipari értékesítés területi megoszlása, 1993

Regional breakdown of industrial sales, 1993

\begin{tabular}{|l|c|c|c|c|}
\hline \multicolumn{1}{|c|}{ Megye } & \multicolumn{2}{c|}{ Összes értékesítés } & \multicolumn{2}{c|}{ Ebböl: export } \\
\hline & millió $\mathrm{Ft}$ & megoszlási \% & millió Ft & megoszlási \% \\
\hline Györ-Moson-Sopron & 118718 & 5,9 & 33004 & 6,8 \\
\hline Vas & 64131 & 3,2 & 25075 & 5,1 \\
\hline Veszprém & 70582 & 3,5 & 20469 & 4,2 \\
\hline Zala & 47207 & 2,3 & 11991 & 2,5 \\
\hline Északnyugat-Dunántúl & 300638 & 14,9 & 90539 & 18,5 \\
\hline Komárom-Esztergom & 80387 & 4,0 & 7878 & 1,6 \\
\hline Fejér & 111924 & 5,6 & 34808 & 7,1 \\
\hline Észak-Dunántúl & 392217 & 24,5 & 133225 & 27,2 \\
\hline Vidék & 1337484 & 66,5 & 317827 & 65,0 \\
\hline Budapest & 673538 & 33,5 & 171079 & 35,0 \\
\hline Ország ósszesen & 2010992 & 100,0 & 488906 & 100,0 \\
\hline
\end{tabular}

Forrás: Megyei statisztikai évkönyvek alapján Horváth Gy. számításai

\section{TÁBLÁZAT}

Az északnyugat-dunántúli ipar exportjának ágazati szerkezete, 1993

Sectoral structure of the industrial export of Nortwest Transdanubia, 1993

\begin{tabular}{|l|r|r|r|r|r|r|r|c|}
\hline \multicolumn{1}{|c|}{ Megye } & \multicolumn{2}{|c|}{ Nehézipar } & \multicolumn{2}{|c|}{ Konnnyüipar } & \multicolumn{2}{c|}{ Élelmiszeripar } & \multicolumn{2}{c|}{ Ipar osszesen } \\
\hline & $\mathrm{M} \mathrm{Ft}$ & \multicolumn{1}{c}{$\%$} & $\mathrm{M} \mathrm{Ft}$ & $\%$ & $\mathrm{M} \mathrm{Ft}$ & $\%$ & $\mathrm{M} \mathrm{Ft}$ & $\%$ \\
\hline Györ-M.-S. & 21774 & 66,0 & 4030 & 12,2 & 4716 & 14,3 & 33004 & 100,0 \\
\hline Vas & 15738 & 62,8 & 6449 & 25,7 & 2822 & 11,3 & 25075 & 100,0 \\
\hline Veszprém & 16967 & 82,9 & 1160 & 5,7 & 1934 & 9,5 & 20469 & 100,0 \\
\hline Zala & 4955 & 41,2 & 2629 & 21,9 & 2842 & 23,7 & 11991 & 100,0 \\
\hline Összesen & 59434 & 65,6 & 14268 & 15,8 & 12314 & 13,6 & 90539 & 100,0 \\
\hline
\end{tabular}

Forrás: Megyei statisztikai évkönyvek alapján Horváth számitásai.

Az összes export 53,3\%-a jut a megyeszékhelyekre (1. ábra), és a városkörzetek exportteljesítménye is erős differenciákat mutat. Az egyes megyék arányait a 2. ábra mutatja, melyen az országos átlag a 100\%-os viszonyítási alap. 
Tér és Társadalom 11. évf. 1997/1. 73-108. p.

\section{1. ÁBRA}

Exportáló települések az Északnyugat-Dunántúlon

(Exporting settlements in North Transdanubia)

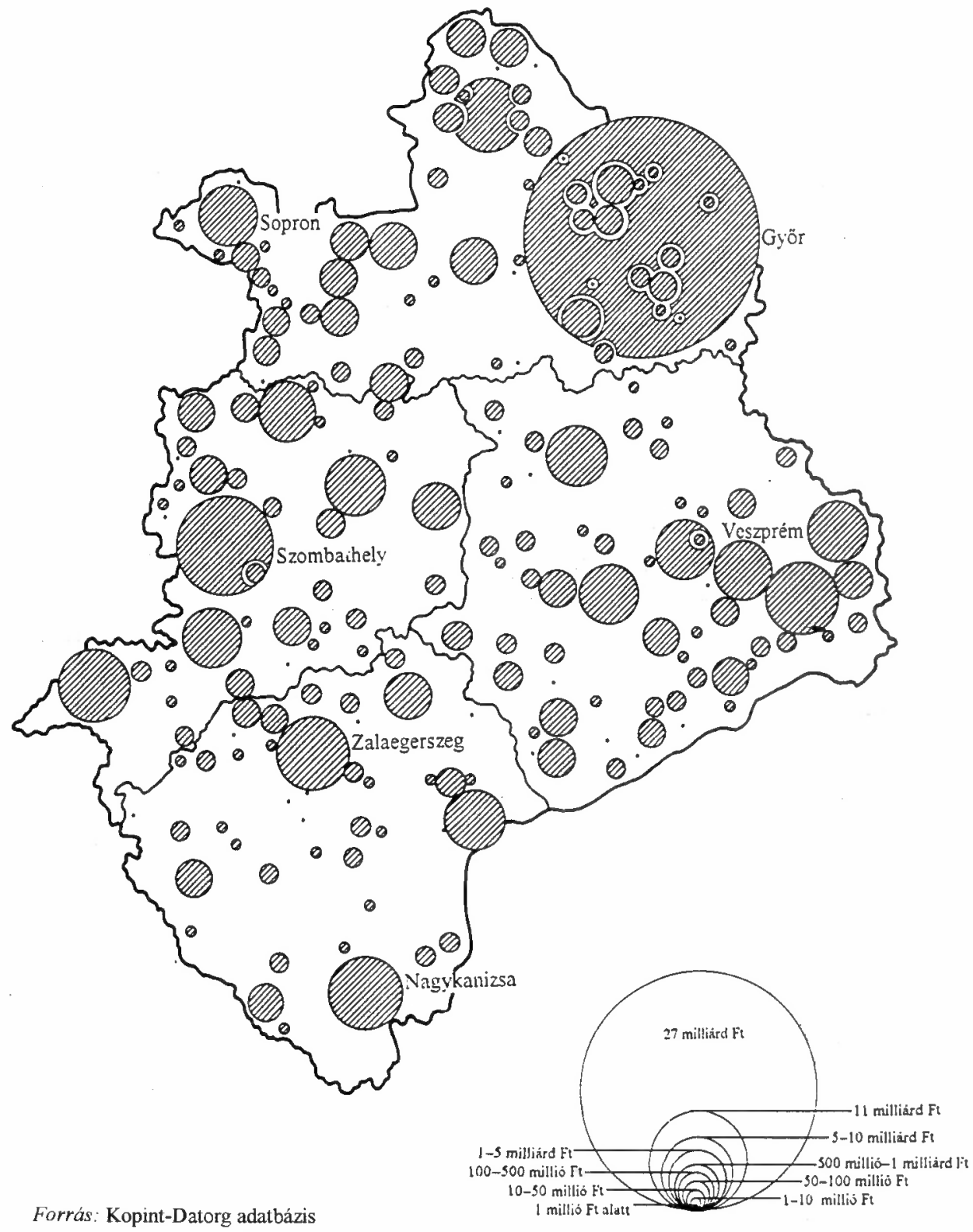




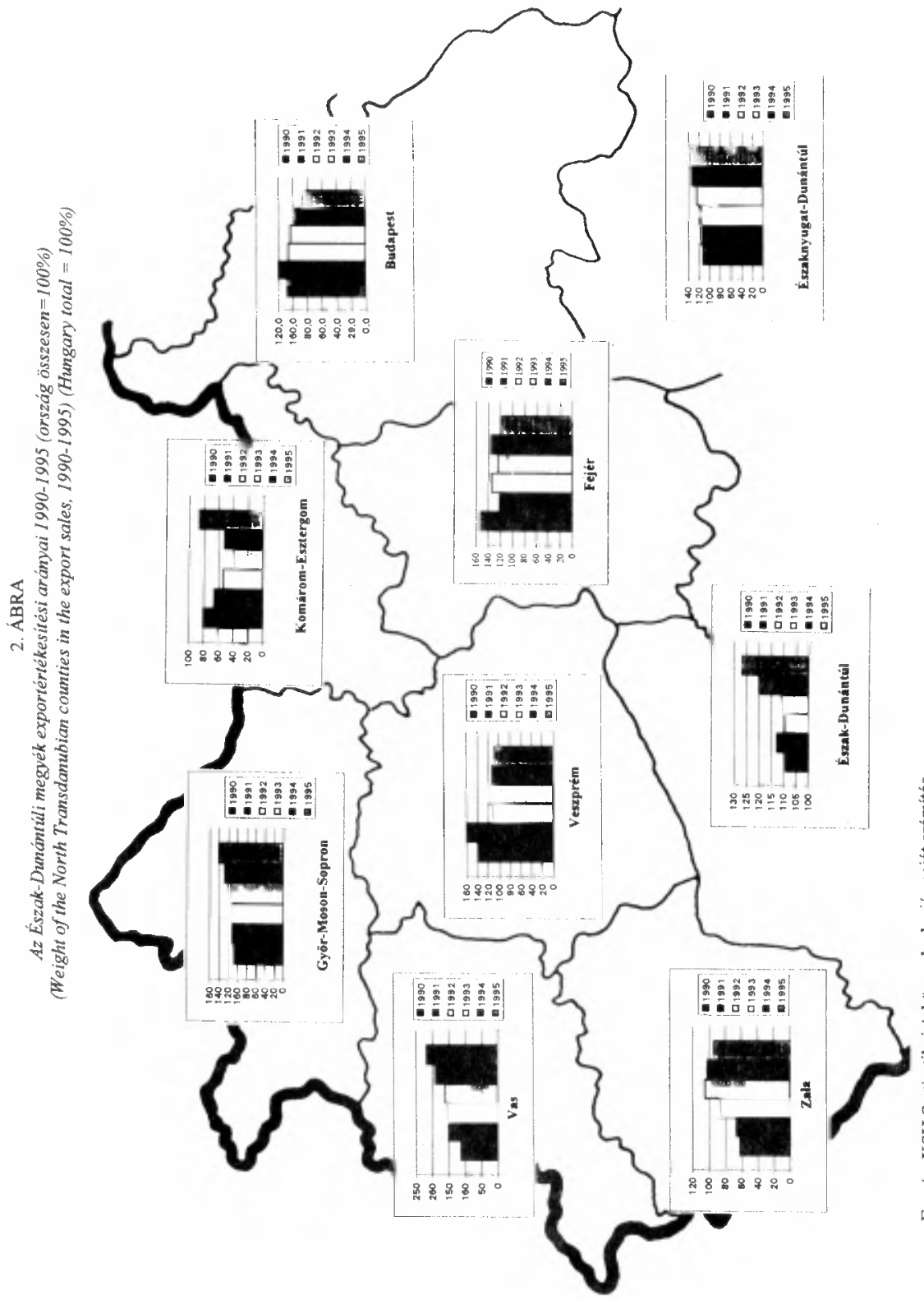




\section{Privatizáció}

$\mathrm{Az}$ 1980-as évek második felében a gazdaságpolitika egy gazdasági rendszerváltozásban látta a hosszú távú gazdasági növekedés biztosítékát, melyet gyakran emlegettek új növekedési pályaként. A renđszerváltozás alapvetően a tervgazdálkodási rendszerből való áttérést jelentette egy szociális piacgazdálkodási rendszerre, illetőleg a szakemberek egy része a liberális piacgazdálkodást látta egyetlen jó megoldásnak. Mindkét irányzat alapja egy átfogó tulajdonreform végrehajtása volt, mely lehetővé tette az egységes állami és a szocialista szövetkezeti tulajdonforma felváltását nagyobb arányú magán- és korlátozott arányú állami tulajdonnal. Kezdeti lépéseit a szocialista vállalatokon belüli különféle munkaközösségek kialakulása jelzi, majd felgyorsul spontán formát öltve az 1988as évi társasági törvény jogerőre emelkedésével, valamint az Állami Vagyonügynökség (ÁVÜ), később az Állami Privatizációs Vagyonügynökség Rt. (ÁPV Rt.) szervezetében, törvények, rendeletek szabályai szerint bonyolítva.

A privatizációs folyamat az egyes piacgazdasági szervezeti formák kialakulásával, változásával jól nyomon követhető.

\subsection{A jogi személyiségũ gazdasági szervezetek 1990-1994 között a térségben és az országban}

A térség jogi és jogi személyiséggel nem rendelkezö gazdasági szervezetei számának felfutását ${ }^{5}$ tükrözi a 9. táblázat.

Az ipar szervezetét alakító eddigi legfontosabb lépések vázlatosan az alábbiak:

- Az első világháború előtt - hasonlóan a fejlett nyugati országokhoz - a magyar ipar legfejlettebb ágazataiban is meghatározóvá váltak az akkor korszerü vállalati szervezeti formák és vezetési típusok, de fennmaradtak a korai kapitalizmusra jellemzök is

- A két világháború között a felemás helyzet konzerválódott.

- után mintegy 1962-64-ig a szervezetkorszerüsítés folyamata elkanyarodott a nyugati országok gyakorlatától, a vállalatok állami tulajdonba kerültek, önállóságuk megszünt, a formalitás következtében funkcióik csak a termelésre korlátozódtak, a kisipar, a kisüzemek gyakorlatilag eltüntek. Az állami tulajdonba került vállalatokat átszervezték, így méretük az összevontak körében megkétszereződött.

- között következett be az első centralizálási hullám, ekkor az azonos ágazatú, méretủ és térségủ vállalatokat egyetlen szervezetbe tömörítették. Méretük újra megkétszereződött.

- között folyt le a harmadik nagy centralizációs hullám, amikor a nagyvállalatok a kis- és középméretủ vállalatokat beolvasztották. Erösen lecsökkent a kis és középméretủ szervezetek száma, mely az iparirányitás centralizálásának erősöđését vonta maga után.

- A rendkívüli méretüre növekedett szervezetek lebontására történtek kísérletek 1968-ban, majd az 1980-as évek elején, de érdemi változást csak az 1988. évi társasági törvény hozott. (Kiss 1995) 
A szervezeti átalakulás általában az ủjra, az innovációra fogékonyabb térségekben következett be gyorsabban, így Budapesten kívül az Észak-Dunántúli térségben, melyben az országos vidéki átlag növekedését jóval meghaladja valamennyi megye növekedése Komárom-Esztergom megye kivételével a jogi személyiségủ társaságok körében. A jogi személyiséggel nem rendelkező társaságok számának növekedését tekintve viszont Komárom-Esztergom és Fejér megye meghaladja a vidéki átlag növekedését, míg a térség többi megyéje elmarad attól. Az egyéni vállalkozók számát vizsgálva egyedül Györ-Moson-Sopron és Fejér megye marad el a vidéki átlag szintjétől.

\section{TÁBLÁZAT}

Gazdasági szervezetek száma Number of economic organisation

\begin{tabular}{|l|r|r|c|c|c|c|c|c|c|}
\hline \multirow{2}{*}{ Megye } & \multicolumn{3}{|c|}{ Jogi szem. gazd. szerv. } & \multicolumn{2}{c|}{ Jogi szem. nélküli gazd. szerv. } & \multicolumn{3}{|c|}{ Egyéni vállalkozó } \\
\cline { 2 - 11 } & 1991 & 1994 & $1994 / 1991$ & 1991 & 1994 & $1994 / 1991$ & 1991 & 1994 & $1994 / 1991$ \\
\hline Györ-M-S & 1866 & 3693 & 197,9 & 3126 & 3749 & 119,9 & 22302 & 31727 & 142,3 \\
\hline Vas & 825 & 1858 & 225,2 & 1514 & 1600 & 105,7 & 6850 & 17329 & 253,0 \\
\hline Veszprém & 1397 & 2689 & 192,5 & 2910 & 2826 & 97,1 & 15058 & 33793 & 224,4 \\
\hline Zala & 1060 & 2099 & 198,0 & 2456 & 3158 & 128,6 & 11691 & 26600 & 227,5 \\
\hline ÉNY-Dunántúl & $51+8$ & 10339 & 200,8 & 10006 & 11333 & 113,3 & 55901 & 82849 & 148,2 \\
\hline Fejér & 1515 & 3246 & 214,3 & 3060 & 4934 & 161,2 & 21686 & 31242 & 144,1 \\
\hline Kom.-Eszt. & 1424 & 2642 & 185,5 & 2388 & 3371 & 141,2 & 2388 & 22386 & 937,4 \\
\hline É-Dunántúl & 8087 & 16227 & 200,7 & 15454 & 19638 & 127,1 & 79975 & 163077 & 203,9 \\
\hline Vidék összesen & 29794 & 56316 & 189,0 & 54987 & 72602 & 132,0 & 385923 & 566276 & 146,7 \\
\hline Budapest & 22962 & 44931 & 195,7 & 28797 & 48526 & 168,5 & 125866 & 211600 & 168,1 \\
\hline Ország összesen & 52756 & 101247 & 191,9 & 83784 & 121128 & 144,6 & 511789 & 778036 & 152,0 \\
\hline
\end{tabular}

Forrás: KSH Statisztikai évkönyvei 1991, 1994

A fóbb gazdasági ágakat tekintve a jogi személyiségú szervezeteket vizsgálva a 10. táblázatból kitünik, hogy a térségben az ipar és a mezőgazdaság részaránya csökkent, a szolgáltató ágazatoké növekedett. Tehát az ország többi részéhez képest a jogi és nem jogi személyiségủ szervezetek átalakulási folyamatában eltérés tapasztalható. Az ország többi részében a nem jogi személyiségú szervezetek száma jobban növekedett jobban, mint az északdunántúli térségben.

\section{A legnagyobb külföldi befektetők 1988-1994 között a térségben}

A legnagyobb külföldi befektetó cégek ${ }^{6}$ túlnyomó részben társtulajdonosokként vegyes vállalatok (Rt., Kff.) alapításában müködtek közre. A vegyes vállalatok (joint ventures) számát az Észak-dunántúli térségben a 11. táblázat tükrözi.

Jól látható, hogy a Budapesten kívüli vidéki befektetésekkel a vegyes vállalatok mintegy egyharmadát az észak-dunántúli térségben hozták létre. Az 1988-as arányok lényegesen megváltoztak az 1995-ig eltelt időszak alatt. A befektetett külföldi tőke részesedését tekintve már csökken 1995-ben a jegyzett tókében. A legnagyobb külföldi részesedés az Észak-Dunántúlon figyelhetỏ meg, ezt a térséget találta legkisebb kockázatúnak a külföldi tőke. Ez arra utal, hogy a befektetéseket stratégiai megfontolások is motiválhatták. 


\section{TÁBLÁZAT}

A jogi személyiségü szervezetek gazdasági ágankénti megoszlása (\%)

Breakdown of organisations with legal entity by economic sectors (in per cent)

\begin{tabular}{|l|c|c|c|c|c|c|c|c|c|}
\hline \multicolumn{1}{|c|}{ Megye } & \multicolumn{3}{c|}{ Ipar+épitöipar } & \multicolumn{3}{c|}{ Mezögazdaság } & \multicolumn{3}{c|}{ Többi ágazat } \\
\hline Györ-M-S. & 1991 & 1994 & 1995 & 1991 & 1994 & 1995 & 1991 & 1994 & 1995 \\
\hline Vas & 32,5 & 25,1 & 19,5 & 7,1 & 8,5 & 3,6 & 60,4 & 66,4 & 76,9 \\
\hline Veszprém & 36,1 & 29,8 & 20,5 & 10,9 & 10,3 & 7,8 & 53,0 & 59,9 & 71,7 \\
\hline Zala & 32,0 & 28,7 & 18,2 & 8,3 & 7,6 & 5,4 & 59,7 & 63,7 & 23,6 \\
\hline ÉNY-Dunántúl & 32,6 & 27,4 & 19,3 & 9,4 & 10,8 & 6,0 & 58,0 & 61,8 & 25,3 \\
\hline Fejér & 40,3 & 27,4 & 19,3 & 8,5 & 9,0 & 5,8 & 58,5 & 63,6 & 74,9 \\
\hline Kom.-Eszt. & 42,6 & 35,7 & 24,4 & 11,2 & 9,6 & 3,7 & 48,5 & 58,6 & 24,1 \\
\hline É-Dunántúl & 36,0 & 29,6 & 20,2 & 8,5 & 6,4 & 3,3 & 51,9 & 57,9 & 72,3 \\
\hline Vidék ósszesen & 37,3 & 31,1 & 20,2 & 9,8 & 9,3 & 5,1 & 55,5 & 61,7 & 74,7 \\
\hline Budapest & 35,2 & 25,9 & 16,0 & 0,7 & 0,7 & 0,7 & 64,1 & 73,4 & 83,3 \\
\hline Ország ósszesen & 36,4 & 28,8 & 18,9 & 5,8 & 5,5 & 3,8 & 57,8 & 65,7 & 77,3 \\
\hline
\end{tabular}

Forrás: KSH Statisztikai évkönyvei 1991, 1994

\section{TÁBLÁZAT}

A vegyes vállalatok száma és megoszlása az észak-dunántúli térségben Number and distribution of joint ventures in the Nortwest Transdanubian region

\begin{tabular}{|c|c|c|c|c|c|c|c|c|c|c|}
\hline \multirow[t]{2}{*}{ Megye } & \multicolumn{2}{|c|}{1988} & \multicolumn{4}{|c|}{1993} & \multicolumn{4}{|c|}{1995} \\
\hline & $\begin{array}{l}\text { szám } \\
\text { (db) }\end{array}$ & $\begin{array}{c}\text { Rész } \\
\text { arány } \\
\%\end{array}$ & $\begin{array}{l}\text { szám } \\
\text { (db) }\end{array}$ & $\begin{array}{c}\text { Rész- } \\
\text { arány } \\
\% \\
\end{array}$ & $\begin{array}{c}\text { Jegyz. } \\
\text { tôke } \\
(\mathrm{M} \mathrm{Ft}) \\
\end{array}$ & $\begin{array}{c}\text { Jegyz. töke } \\
\text { külf. r.a. } \\
\% \text {-a }\end{array}$ & $\begin{array}{l}\text { szám } \\
\text { (db) }\end{array}$ & $\begin{array}{c}\text { Rész- } \\
\text { arány } \\
\%\end{array}$ & $\begin{array}{l}\text { Jegyz } \\
\text { tőke } \\
\text { (M Ft) } \\
\end{array}$ & $\begin{array}{c}\text { Jegyz töke } \\
\text { külf.. r.a. } \\
\% \text {-a }\end{array}$ \\
\hline Győr-M-S & 7 & 3,1 & 930 & 4,4 & 37,4 & 64,2 & 1247 & 5,0 & 114 & 63,2 \\
\hline Vas & 3 & 1,3 & 525 & 2,5 & 22 & 88,6 & 271 & 1,1 & 46 & 87,0 \\
\hline Veszprém & 5 & 2,2 & 585 & 2,8 & 13,8 & 50,7 & 749 & 3,0 & 23 & 65,2 \\
\hline Zala & 4 & 1,8 & 551 & 2,6 & 14,8 & 66,9 & 1069 & 4,3 & 31 & 74,2 \\
\hline ENY-Dunántül & 19 & 8,4 & 2591 & $I 2,3$ & 88 & 68,6 & 3336 & 13,4 & $21+$ & 70,1 \\
\hline Fejér & 3 & n. a. & 439 & 2,1 & 40,8 & 62,7 & 515 & 2,1 & 53 & 75,5 \\
\hline Kom.-Eszt. & 9 & 4,0 & 446 & 2,1 & 35,7 & 59,7 & 471 & 1,9 & 49 & 71,4 \\
\hline E-Dunántúl & 31 & n. $a$. & $3+76$ & 16,6 & $16+, 5$ & 65,2 & +322 & $\overline{17,3}$ & 316 & 71,2 \\
\hline Vidék összesen & 80 & 35,2 & 10046 & 47,8 & 388,1 & 64,7 & 12827 & 51,4 & 864 & 66,0 \\
\hline Budapest & 147 & 64,8 & 10953 & 52,2 & 725,1 & 56,8 & 12123 & 48,6 & 1109 & 66,6 \\
\hline Ország összesen & 227 & 100,0 & 20999 & 100,0 & 1113 & 59,5 & 24950 & 100,0 & 1973 & 66,0 \\
\hline
\end{tabular}

Forrás: Nagy Gábor: A külföldi töke szerepe és térbeli terjedése Magyarországon (Tét 1995/1-2. sz. 66. p.), valamint KSH Területi Statisztikai Évkönyvek, KSH A külföldi múkôdő tőke Magyarországon 1994. Bp., 1996.

Országosan a legnagyobb befektetőknek Németország. Ausztria és az USA bizonyult 1993-94-ben, együttesen mintegy 350-400 milliárd Ft-ot fektettek be Magyarországon. Az összes invesztált tőke értéke 533,2-713,8 milliárd $\mathrm{Ft}$ volt. Ebböl Budapesté összesen 370,1-422 milliárd Ft, az Északnyugat Dunántúlé 
összesen 36,8-72,6 milliárd Ft (6,9\%-10,2\%), az Észak-Dunántúlon pedig 73,6125,3 milliárd Ft (13,8\%-17,6\%). Az ország többi (13) megyéje között oszlik el a maradék 16,8\%-23,3\%-ot kitevő, mintegy 89,6-166,3 milliárd $\mathrm{Ft}$

Értékben megduplázódott a két év folyamán, ezért feltehetően a többi megyében is egyre több vállalkozás kerül külföldi befektetők teljes vagy többségi tulajdonába.

Tehát a befektetett tóke nagyságát tekintve az északdunántúli térséget preferálták Budapest után a legjobban a külföldi befektetók.

\section{TÁBLÁZAT}

A külföldi befektetések alakulása országok szerint, 1993-1994 (\%)

Foreign inward investments by countries, 1993-1994 (in per cent)

\begin{tabular}{|c|c|c|c|c|c|c|c|c|c|}
\hline Megye & Gy-M-S. & Vas & Veszprém & Zala & Fejér & Komárom- & Budapest & \multicolumn{2}{|c|}{ Ország összesen } \\
\hline & \multicolumn{7}{|c|}{ Országok szerinti részarányok (\%) } & Mrd Ft & $\begin{array}{c}\text { Megoszlási } \\
\text { arány }\end{array}$ \\
\hline Németország 1993 & 12,7 & 39,5 & 18,8 & 20,4 & 6,5 & 9,5 & 31,3 & 151,6 & 28,4 \\
\hline 1994 & 12,0 & 57,8 & 21,9 & 20,7 & 7,1 & 16,3 & 21,0 & 159,1 & 22,3 \\
\hline Ausztria 1993 & 57,6 & 9,3 & 46,9 & 20,4 & 24,1 & 6,5 & 13,6 & 84,4 & 15,8 \\
\hline 1994 & 51,8 & 24,0 & 28,8 & 28,9 & 20,4 & 5,8 & 19,9 & 142,0 & 19,9 \\
\hline USA 1993 & 0,0 & 40,3 & 3,1 & 0,0 & 44,7 & 4,1 & 23,6 & 112,0 & 21,0 \\
\hline 1994 & 2,2 & 2,3 & 4,1 & 5,0 & 40,2 & 5,0 & 18,0 & 101,8 & 14,3 \\
\hline Hollandia 1993 & 15,8 & 0,0 & 0,0 & 0,0 & 1,5 & 3,6 & 6,2 & 30,1 & 5,6 \\
\hline 1994 & 10.9 & 0,4 & +.1 & 4.1 & 12,3 & 13,6 & 12,2 & 79,4 & 11,1 \\
\hline Franciaország 1993 & 2,5 & 0,8 & 0,0 & 0,0 & 0,5 & 3,0 & 4,5 & 25,3 & 4,7 \\
\hline 1994 & 2,6 & 0,4 & 13,7 & 0,0 & 3,3 & 1,9 & 5,1 & 37,1 & 5,2 \\
\hline $\begin{array}{r}\text { Egyesült Királyság } \\
1993 \\
\end{array}$ & 3,8 & 3,1 & 3,1 & 24,5 & 0,0 & 0,6 & 3,2 & 20,9 & 3,9 \\
\hline 1994 & 12,0 & 3,5 & 6,8 & 0,0 & 0,0 & 0,4 & 4,3 & 32,0 & 4.5 \\
\hline Olaszország 1993 & 1,3 & 3,1 & 12,5 & 0,0 & 5,5 & 0,0 & 3,7 & 20,6 & 3,9 \\
\hline 1994 & 0.7 & 5,8 & 8,2 & 1,7 & 5,2 & 1,6 & 3,7 & 33.3 & 4,7 \\
\hline Svájc 1993 & 2,5 & 2,3 & 3,1 & 2,0 & 0,0 & 3,6 & 1,2 & 10,4 & 2,0 \\
\hline 1994 & 1,8 & 2,7 & 0,0 & 1.7 & 11,5 & 3,1 & 2,8 & 27,4 & 3,8 \\
\hline Egyéb 1993 & 3,8 & 1,6 & 12,5 & 32,7 & 17,2 & 69,1 & 12,7 & 77,9 & 14,7 \\
\hline 1994 & 6,0 & 3,1 & 12,4 & 37,9 & 0,0 & 52,3 & 13,0 & 101,7 & 14,2 \\
\hline Összesen 1993 & 100 & 100 & 100 & 100 & 100 & 100 & 100 & 533,2 & 100 \\
\hline 1994 & 100 & 100 & 100 & 100 & 100 & 100 & 100 & $7 / 3,8$ & 100 \\
\hline
\end{tabular}

Forrás: KSH A külföldi mủködő tőke Magyarországon 1994. Bp., 1996.

Vizsgálataink alapjản a befektető cégeket az alábbi tényezők megléte, illetőleg hiányosságai befolyásolták befektetési döntéseik helyének megválasztásában a térségben:

- a már létezö befektetők lokális koncentrációja, 
- a földrajzi helyzet, mint a különféle kapcsolatok (termelési, értékesítési, közlekedési információs) lehetőségétöl való távolság,

- a letelepedés helyének és környékének gazdasági és kulturális fejlettsége,

- a helyi hatalom különféle támogatásai (pl. földterület biztosítása, különféle kedvezmények stb.),

- a központi hatalom regionális, lokális támogatási rendszere.

\section{Telepitési tényezók}

Nemzetközi felmérések szerint a telepítési tényezök közül sorrendben a beruházó vállalkozó az alábbi tényezőknek tulajdonít különleges jelentőséget:

- az infrastruktúra minőségének (a fizikai infrastruktúra fokozatosan háttérbe szorul, s előtérbe lép a technológiai, a távközlési és a humán infrastruktúra, mert a termelési és értékesítési folyamatok bonyolultsága és diverzifikáltsága sokrétú információkat, magasan kvalifikált, müszaki-gazdasági szakembereket igényel),

- az általános ipari lehetőségeknek (a gépipari és elektronikai berendezéseket gyártó befektetö erősen érdekelt az ipari termelés és a kapcsolódó szolgáltatások mủködő hálózatában, a háttéripar fejlettségében, a karbantartó kapacitások kiépítettségében, a település számítógépparkjának és adatfeldolgozási rendszereinek a meglétében és minöségében),

- a piacra jutás feltételeinek (a telepitési hely piaci volumene mellett a szomszédos piacokra való kijutás adottságai, a más országok piacainak megközelíthetősége, az ehhez szükséges szervezeti, információs és szellemi háttér jelenléte),

- az engedélyezési eljárások hatékonyságának (egyszerủ eljárási mechanizmusok, az ügyintézés rövidsége ${ }^{7}$, szervezeti koncentrációja),

- a makrogazdasági szabályozásnak (Kiszámítható, stabil gazdaságpolitika, reális árfolyam).

Szinte valamennyi nemzetközi üzleti felmérésben a megkérdezett befektetők az első három tényezőre helyezik a hangsúlyt. Ez azt jelenti, hogy ezek olyan belsỏ, a településeken, vagy környezetükben létező tényezők, amelyek kifejlesztésében kínálatuk szervezésében, a kínálati pozíciók propagálásában, a kủlföldi partnerekkel való megismertetésükben a helyi és a területi önkormányzatoknak nagy a szerepük míg a rangsor többi tényezője inkább a központi gazdaságpolitika kompetenciájába tartozik.

A telepítési tényezők nagyfokú mobilitása az európai piacon a települések és régiók kölcsönhatásait erősíti, ez pedig a kooperációval egyidejüleg az országrészek és városok konkurenciaharcát is eredményezheti. Azonban egy gazdasági vagy ipari körzet kialakulása és teljesítése inkább a telepitési tényezők által biztositott vagy fenntartott körzeti életképesség függvénye, melyben a konkurencia is csak egy elem. (Zeitlin 1994) 
Az észak-nyugat dunántúli területfejlesztési stratégia kidolgozásához és a térségi konjunkturakutató intézetet megalapozó vizsgálat során intézetünk megkérdezte a térség nagyvállalatait arról, milyen telepítési tényezőket tartanak fontosnak telephely létesítése esetén adott településen.

A válaszként megadott és az általuk meghatározott lehetséges telepítési tényezök között az alábbiakat sorolták a sorrendet állították fel Veszprém városban és a megyében (az értékelésben az ötös azt jelentette, hogy a legfontosabb, az egyes pedig azt, hogy a legkevésbé lényeges):

- helyi, vagy gyorsan elérhető pénzügyi szolgáltatások

- piaci, értékesítési információkat kínáló szervezetek

- vállalkozói hajlandóság

- közúti közlekedési kapcsolatok

- helyi, térségi termelési (beszállítási) kapcsolatok

- kommunális infrastrukturális ellátottság

- szociális infrastrukturális ellátottság

A nagyvállalatok tulajdonképpen a felsorolt települési jellemző ${ }^{8}$ nagy részét legalább közepesen fontosnak tartják telephely létesítés szempontjából. Ez azt jelenti a települések számára, hogy a vállalkozások megtelepedéséért folyó versenyben annak a településnek van nagyobb esélye a győzelemre, amelyik a fontosnak tartott infrastrukturális tényezök legtöbbjével rendelkezik, vagy rövid időn belül „produkálni tudja" azokat legalább a minimálisan szükséges szinten.

A kormányzati politika befolyásoló hatásáról, mint telepítési tényezőről az alábbi értékelés született:

\section{TÁBLÁZAT}

Kormányzati politikától függó tényezók gazdálkodást befolyásoló hatása

The impact on government policy dependant factors on the economy

\begin{tabular}{|l|c|}
\hline \multicolumn{1}{|c|}{ Tényezök megnevezése } & Ipar összesen \\
\hline kormányzati adók, illetékek mértéke & 3,8 \\
\hline gazdaság jogi kőrnyezete & 3,2 \\
\hline bankhitelek kondíciói & 3,2 \\
\hline vállalkozás támogatás jelenlegi rendszere & 2,6 \\
\hline forint árfolyam politika & 2,4 \\
\hline
\end{tabular}

Forrás: Nagyvállalatok kérdőíves megkérdezése, saját feldolgozás (1996)

A vállalkozások (mind a kis-, a közép-, és a nagyvállalkozások) sikeres tevékenysége és gazdálkodása, profittermelése érdekében a lokális tényezőkön túl szükségesnek ítélték a kormányzati gazdaság- és iparpolitika vállalkozásbarát megfogalmazását és érvényesítését. Ez piacgazdasági körülmények között bonyolult és összehangolt szabályozást igényel a nemzetgazdaság valamennyi szereplöje részéről. Az összhang megléte vagy hiánya a vállalkozások pénzügyi környezetének szabályozásában érhető tetten a legjobban. Ezért a beruházásaikat korlátozó tényezốk a vállalkozások hosszú távú fennmaradását is korlátok közé szorítják, vagy éppenséggel lehetetlenné teszik, megszüntetik tevékenységüket a fejlesztések meghiúsítás ‘̂val. 


\section{Máthé Mária :}

Északnyugat-Dunántúl gazdasági és ipari szerkezetének átalakulása

Tér és Társadalom 11. évf. 1997/1. 73-108. p.

\section{TÁBLÁZAT}

A beruházási terveket legjobban korlátozó tényezők

Factos most restricting investment plans

\begin{tabular}{|l|r|r|r|r|r|r|r|}
\hline \multicolumn{1}{|c|}{ Korlátozó tényezó } & $\begin{array}{c}\text { Élelmi- } \\
\text { szer } \\
\text { gazd. }\end{array}$ & Ipar & $\begin{array}{c}\text { Épitö- } \\
\text { ipar }\end{array}$ & $\begin{array}{r}\text { Kereske- } \\
\text { delem }\end{array}$ & $\begin{array}{c}\text { Szállitás, } \\
\text { távközlés }\end{array}$ & $\begin{array}{c}\text { Szolgál- } \\
\text { tatások }\end{array}$ & $\begin{array}{c}\text { Nemzet- } \\
\text { gazd. } \\
\text { osszesen }\end{array}$ \\
\hline 1. Elégtelen kereslet & 19,5 & 21,3 & 28,6 & 31,1 & 16,7 & 28,1 & 21,8 \\
\hline 2. Hitelhez jutás néézségei & 37,7 & 38,6 & 57,1 & 31,9 & 29,2 & 28,1 & 32,0 \\
\hline 3. Egyéb tökéhez jutás nehézségei & 26,0 & 24,0 & 28,6 & 19,3 & 25,0 & 21,9 & 21,0 \\
\hline $\begin{array}{l}\text { 4. Magas beruházási } \\
\text { hitelkamatok }\end{array}$ & 50,6 & 52,9 & 57,1 & 42,2 & 70,8 & 32,8 & 43,3 \\
\hline 5. Gyenge profitkilátások & 36,4 & 33,7 & 39,3 & 29,6 & 54,2 & 34,2 & 31,3 \\
\hline 6. Eladósodás veszélye & 42,9 & 44,1 & 60,7 & 34,8 & 54,2 & 29,7 & 37,6 \\
\hline 7. Technikai tényezók & 9,1 & 7,6 & 3,6 & 3,7 & 12,5 & 12,5 & 6,4 \\
\hline
\end{tabular}

Forrás: Ahogy a vállalkozások látják az 1996. évet. (Felmérés a kilátásokról és szándékokról) 1996. GKI Gazdaságkutató Rt., Budapest Függelék 6. old.

A felmérést A GKI Gazdaságkutató Rt. készitette (1996), melynek alapja a minden megyét átfogó kérdőíves feldolgozás. A felmérés az ország valamennyi megyéje vállalkozásainak körében készült, melyben az egyes megyékből mintegy $50-100$ vállalat képviselte az adott megyei mintát. A beruházásokat akadályozó fỏbb tényezők a vállalkozások szerint országosan tehát:

- a beruházási hitelkamatok mértéke

- az eladósodástól való félelem

- a hitelhez jutás nehézségei.

A magas kamatok érzékenyen érintik az épitöipart és az ipar egészét. Az eladósodástól mégis inkább a szállítási és távkőzlési szolgáltatások vállalkozásai tartanak a legjobban. A szolgáltatások ugyanis erősen függnek a belföldi fizetöképes kereslettől, másik oldalról viszont fogyasztásukat az érvényesithetö (ezáltal a kamatok megtérülési esélyeit is befolyásoló) szolgáltatási dijjak korlátozzák, ha túl magasak a reálkeresetekhez képest. Magasabb inflációs ráta nem kedvez sem a szolgáltatást, sem a hiteleket fogyasztóknak.

\section{TÁBLÁZAT \\ A javasolt gazdaságpolitikai lépések \\ Recommended measures for economic policy}

\begin{tabular}{|c|c|c|c|c|c|c|c|}
\hline Javaslat & $\begin{array}{l}\text { Élelmi- } \\
\text { szer } \\
\text { gazd. }\end{array}$ & Ipar & $\begin{array}{l}\text { Építö- } \\
\text { ipar }\end{array}$ & $\begin{array}{c}\text { Kereske- } \\
\text { delem }\end{array}$ & $\begin{array}{l}\text { Szállítás, } \\
\text { távközlés }\end{array}$ & $\begin{array}{c}\text { Szolgál- } \\
\text { tatások }\end{array}$ & $\begin{array}{l}\text { Nemzet- } \\
\text { gazd. } \\
\text { osszesen }\end{array}$ \\
\hline $\begin{array}{l}\text { 1. Adminisztrativ kötelezettségek } \\
\text { csökkentése }\end{array}$ & 27,3 & 28,9 & 42,9 & 38,5 & 12,5 & 34,4 & 28,6 \\
\hline 2. Banki, tanácsadói szolg. fejlesztése & 7,8 & 10,9 & 17,9 & 12,6 & 4,2 & 14,1 & 11,0 \\
\hline 3. Állami beruházási szubvenciók & 31,2 & 31,0 & 21,4 & 14,1 & 66,7 & 23,4 & 24,1 \\
\hline 4. A forint leértékelése & 11,7 & 12,2 & 0 & 4,4 & 4,2 & 1,6 & 7,0 \\
\hline 5. $\mathrm{Az}$ adók csökkentése & 77,9 & 79,3 & 75,0 & 88,9 & 83,3 & 82,8 & 72,6 \\
\hline 6. TB-járulék csökkentése & 79,2 & 77,8 & 92,9 & 84,4 & 70,8 & 84,4 & 71,5 \\
\hline 7. Vámok növelése & 5,2 & 6,1 & 0 & 4,4 & 0 & 0 & 4,4 \\
\hline $\begin{array}{l}\text { 8. Gazdasági būnözés elleni törvények } \\
\text { meghozatala és alkalmazása }\end{array}$ & 27,3 & 18,2 & 28,6 & 33,3 & 16,7 & 18,8 & 21,8 \\
\hline
\end{tabular}

Forrás: Ahogy a vállalkozások látják az 1996. évet. (Felmérés a kilátásokról és szándékokról) 1996. GKI Gazdaságkutató Rt., Budapest Függelék 13. old. 
A GKI felmérése (valamennyi nagyságú vállalkozásban) és az MTA RKK NYUTI északdunántúli (közép- és nagyvállalatokban) felméréseinek eredményei a gazdaságpolitika vonatkozásában összhangban állnak egymással, mindkét felmérés értelmében csökkentő változtatást javasoltak a megkérdezett vállalkozások:

- a központi elvonások mértékében

- a hitelkamatok mértékében.

A két fó feladat megoldása alapos átgondolását jelenti az egész gazdaságpolitikának, nem egyszerúen csak az ipar vonatkozásában, hanem valamennyi ágazat és a térségek szintjén is.

Mivel a pénzügyi tényezök is beletartoznak a telepítési tényezők körébe, különösen egy adott térség esetében, mert automatikusan egy másik térség, illetve település válik versenyképesebbé a befektetök számảra, ha e tényezỏk gyengék. Ez nemcsak a külföldi, a lehetséges hazai befektetök esetében is igaz lehet. Az érvényesíthetô "redisztribúció" és tőkekivonás (hitelkamatokkal) határa ott lehet, ahonnan kezdve már lehetetlenné válik a térség értékmegőrző, pótló, megújító beruházási tőkeszủkségletének összegyüjtése a meghagyott jövedelemtömegből.

\section{Az észak-dunántúli térség önkormányzatai szerkezetătalakulást segitö tevékenysége}

Az önkormányzatok ipari szerkezet-átalakítást segitő tevékenységének vizsgálatához a korábbi kutatásainkat ${ }^{9}$ kiegészítve az északnyugat-dunántúli stratégia megfogalmazását megalapozó kutatásainkkal, azok eredményére támaszkodva körvonalazhatók a vállalkozások és az önkormányzatok közötti kapcsolatrendszer elemei. Az önkormányzatok saját vállalkozói, vagyonkezelöi tevékenységükön túlmenöen a vállalkozásokat területükön a következő módon támogathatják:

- infrastruktúra kiépítésével, melyekhez az elkủlönített állami pénzalapokat megpályázzák

- iparfejlesztési alap múködtetésével

- helyi adókedvezményekkel

- megrendelések adásával a közbeszerzési törvény értelmében

- esetleg pénzeszközök átadásával

- kedvezményes hitellel (pl. központi pályázatok saját része)

- kedvezó bérleményekkel (nem lakás célú)

- egyéb létesítmények (pl. ipari parkok, inkubátorházak) megvalósításának támogatásával

- területbiztosítással. (Máthé 1993)

Mindezen eszközöket az egyes önkormányzati hierarchikus szintek eltérỏ módon alkalmazták, vagy nem tudták, vagy nem is törekedtek az alkalmazásukra. 
a./ A vállalkozások értékelése az ipari szerkezetátalakulást segítő északnyugat dunántúli megyei önkormányzatok tevékenységéröl

A régióbeli megyei önkormányzatok az általuk megfogalmazott és követett megyei gazdaság- és iparfejlesztési stratégiával általában nem rendelkeztek, a vállalkozások viszont nagyon fontosnak tartják szerepüket. Föként a regionális piaccal rendelkezök müködésüik, kapcsolódási, beszállitási lehetőségek szempontjából. A térségben mủködỏ vállalatok értékelése ${ }^{11}$ alapján a legtöbb pontot a következő megyei önkormányzati fejlesztési célok kapták az alábbi sorrendben:

- idegenforgalom és turizmus fejlesztése

- a kis és középvállalatok müködési feltételeinek javitása

- a magas szintú szellemi munkára épülö dinamikus iparágak fejlesztése

- a szellemi erőforrások bővítése (felsőoktatás, kutatás-fejlesztés)

- a külföldi múködő tőke fogadási feltételeinek javítása.

A beruházási forrásokhoz való hozzáférés (koncentrált hitelek, gazdaságfejlesztést célzó elkülönített állami alapok támogatásai a közép és nagyvállalati körben) gyakorlati kritikájának is tekinthető ez a sorrend, hiszen az északdunántúli térségekben jóval több versenyképessé tehető vállalkozás müködik, mint országosan a koncentrált támogatásban részesült nagyvállalatok együttes száma.

b./ Önkormányzatok értékelése saját vállalkozás-támogató tevékenységükröl ${ }^{11}$ Megyei önkormányzatok értékelése

$\mathrm{Az}$ egyes régióbeli megyei és városi önkormányzatok szakértőivel készített kérdőives felmérés és interjúk alapján néhány fontos terület- és iparpolitikai megállapítás tehető az alkalmazott gyakorlat alapján:

- a megyei önkormányzatok egyöntetủen lényegesnek tartották területük iparfejlesztési koncepciójának elkészítését, jelenleg a régióban egyik megye sem rendelkezik - kivéve Györ-Moson-Sopron - ilyen stratégiai tervvel.

- valamennyi megyei önkormányzat kifejtette, hogy nem tartozik hatáskörébe egyetlen iparfejlesztést segítỏ támogatási forma (fenti felsorolás) kompetenciája, csak koordinativ tevékenységet folytathat saját elhatározásból,

- a megyei önkormányzatoknak tudomása van arról, hogy a helyi önkormányzatok az egyes (fenti felsorolású) támogatási formákat alkalmazzák az iparfejlesztési alap kivételével,

- tapasztalataik szerint általában az olcsó, vagy ingyenes földterület biztosítása a leggyakrabban alkalmazott támogatási forma a helyi önkormányzatoknál,

- adókedvezmények nyújtása bizonyult a leghatékonyabb formának,

- a megyei önkormányzatok a vállalkozás- és iparfejlesztést segítö intézményekröol ${ }^{12}$ nem mindegyik esetében rendelkeztek kellö információval, ezért föként a Vállalkozásfejlesztési Alapítvány alapító és támogató szerepkörét tartották fontosnak. A helyi önkormányzatok alapító, támogató tevékenységgel viszont többféle intézmény (ipari parkok, inkubátorházak, kockázati tőketársaság, innovációs központ, vagyonkezelö profitérdekeltségü gazdasági szervezet, vámszabadterület, vállalkozói zónák ÁRT-beli területbiztositása) müködésében is részt vesznek. 
Az önkormányzatok a terület- és iparfejlesztés legfőbb gátló, akadályozó tényezőinek sorrendben az alábbiakat tartották:

- a helyi bázis, a szellemi potenciál és konkrét cselekvési program hiánya,

- a tỏkehiány, a gazdasági folyamatok teljesen szabadon hagyása, a vállalkozások központi túladóztatása ${ }^{13}$, a redisztribúció rendszere, a túlzott jövedelemelszivás, a kamatpolitika, a kapkodó és követhetetlen szabályozás, a privatizációs gyakorlat miatti instabil gazdasági kömyezet,

- a gazdaságfejlesztési központi pályázatokról az adott megyét érintő megyei információhiány, azaz az egyes megyei önkormányzatok nem tudnak a területükön megvalósuló fejlesztési projektekröl, melyeket a központi elkülỏnített állami alapok pályázati rendszere támogatott. Így a megyei gazdaságfejlesztésben koordináló megyei önkormányzat időnként furcsa helyzetekben találta és találja magát. Egyúttal bizonytalanok abban a kérdésben is, hogy a térségi és a helyi gazdaságfejlesztés, az iparfejlesztés mely hierarchikus szervezet (területfejlesztési tanács vagy önkormányzat) hatáskörében lesz a jövőben és milyen feladatokkal, kompetenciákkal.

Összefoglalóan megállapítjăk, hogy elsősorban a makrogazdasági szintjén kellene a gazdaság- és iparfejlesztési problémákra megoldást találni, viszont ha ez nem lehetséges, akkor kiemelt szerepet kell kapnia a konjunktúra-elemzésekkel is alátámasztott gazdasági klaszterekre, térségekre, körzetekre épưlö regionális szintủ gazdaságirányításnak.

Ezért a térségi terület- és iparpolitikával kapcsolatban az alábbi elvárásokat fogalmazták meg:

- mutassa meg az adott terület adottságait, a rájuk építhető lehetőségeket és fogalmazza meg a teendőket,

- határozza meg, mit kell tenni a vállalkozások helyi és térségi fogadóképességének javítása érdekében,

- vizsgálja meg, hogy a területi adottságokon alapuló lehetőségekhez képest konzisztensek e a makrogazdasági szabályozás által biztosított mozgásterek, ha pedig nem, akkor mivel biztosítható a konzisztencia,

- konkrét fejlesztési projekteket alapozzon meg,

- a finanszírozás forráslehetőségeit tárja fel,

- segítse elỏ a regionális piacok kialakulását, a potenciális régióbeli partnerek egymásra találását.

\section{Helyi önkormányzatok értékelése}

Az interjúk elemzése során megállapítottuk, hogy jelenleg képviselötestület által elfogadott önálló terület- és iparfejlesztési stratégiával, koncepcióval a térség egyetlen települése, városa sem rendelkezik Győr-Moson-Sopron és Veszprém megye kivételével. A követendỏ fejlesztési irányokat a létezö megyei területfejlesztési koncepció alfejezetei fogalmazzák meg. A helyi önkormányzatok az iparfejlesztési alapon kívül valamennyi fejlesztési eszközt alkalmazták a helyi gazdaság és területfejlesztésre, módozatait önkormányzati rendeletekben szabályozták. Az alkalmazás gyakoriságát tekintve a helyi önkormányzatoknál első 
helyen áll az ingyenes földterület biztosítása, a leghatékonyabb eszköznek viszont a kedvezményes ingatlan bérleti díj és a helyi adókedvezmények adása bizonyult.

A vállalkozásokat segító intézmények közül alapítóként és/vagy támogatóként (csak elvétve müködtetöként) a vámszabad-területek ${ }^{14}$, a kockázati töketársaság, a vállalkozói központ (MVA), vállalkozásfejlesztési ügynökség, inkubátorház, ipari park, innovációs központ, vállalkozói zóna, valamint vagyonkezelö profitérdekeltségủ szervezet múködtetésében vesznek részt a helyi önkormányzatok.

A kérdöives felmérés ${ }^{15} 11$ helyi önkormányzat bevonásával zajlotta térség területén, mely alapján a hatékonyság szempontjából az alábbi rangsort állították fel az iparfejlesztési eszközök között:

- helyi adókedvezmények

- kedvezményes bérleti díjak

- ingyenes vagy kedvezményes letelepedési támogatás

- iparfejlesztési alap a helyi vállalkozási adókból

- iparfejlesztési alap központi normatív támogatásból

- önkormányzatnak nyújtott kedvezményes hitel iparfejlesztésre

- központi alapok elosztásában helyi önkormányzati részvétel

- központi alapok decentralizálása

A kérdőíves rangsorolást és az interjút adó önkormányzati szakértök köre eltért egymástól, ezért objektíve a leghatékonyabb helyi gazdaság- és iparfejlesztési eszközöknek tekinthetők a térségben az önkormányzatok által nyújtott adókedvezmények és a kedvezményes bérleti dijak. (Rövid távon persze önkormányzati bevételkiesést okoznak.)

\section{Az észak-dunántúli térség iparfejlesztésre ható tényezők rendszere}

6.1. Iparpolitikai általános elvek (Nemzeti Területfejlesztési Koncepció tervezet megfogalmazásában, továbbiakban NTK)

A közép- és hosszú távú iparpolitikai stratégia fö, meghatározó eleme a szerkezetváltás, mert a magyar ipar fejlődését, alkalmazkodási irányait a világgazdasági folyamatok határozzák meg. Ebből következően a szerkezetváltozás fö́ irányait az NTK:

- az anyag és energiaigényes ágazatok súlyának csökkenésében,

- az élómunka, a $\mathrm{K}+\mathrm{F}$ igényes ágazatok arányának, a világkereskedelemben, a nemzetközi munkamegosztásban jelentős szerepet elfoglaló szakágazatok, termékcsoportok részesedésének növelésében jelöli ki.

Meghatározó feltételeihez sorolja:

- a stabilizáció, a vállalati konszolidáció és a kiegyensúlyozott ágazati struktúra és piaci kapcsolatrendszer,

- hitelképesség és piacépítés,

- a vagyonfölélés megszünése,

- felhalmozási képesség kialakulása.

Mindezek megvalósulásában fontos szerepet szán a:

- ráfordítás-érzékenységnek, a 
- kismértékü környezetterhelésnek, és az

- innováció érzékenységnek.

Fejlödési lehetöségekkel rendelkezỏ ágazatokként említi az élelmiszeripart, a gépipar egyes szektorait, az elektronikai ipart, a vegyi és gyógyszeripart, a logisztikát, és a környezetvédelmi ipart, valamint valószínüsíti azt, hogy az információs forradalom igényei szerint lényegesen át fog alakulni az ipar egésze. Mindezeket követnie kell a hazai innovációnak, a kutatás és fejlesztési

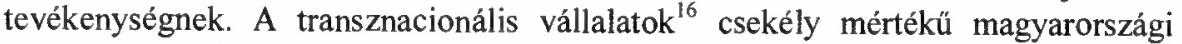
$\mathrm{K}+\mathrm{F}$ érdekeltsége és a hazai vállalkozói szféra szükös lehetőségei miatt állami támogatásra van szükség, melyet új típusúan, az oktatás-képzéshez és a piaci felhasználáshoz alkalmazott formában szükséges megvalósítani.

A hazai ipart három dimenzióban szemléli, az egyes dimenziók:

- multinacionális vállalatok

- hazai nagyvállalatok

- kis- és középvállalatok tömege

Az ipar piacépítésének fö meghatározó tényezőinek tartja az exportnövelést, a hosszú távú nettó tőkebevonást, a vagyonfelélés megszünését és a müködö hitelbank-rendszert.

$\mathrm{Az}$ állam e folyamatban gazdasági ösztönzöket (export-, beruházás-, környezetvédelem) alkalmaz, valamint ágazati és térségi reorganizációs és válságenyhítỏ programokat támogat.

Lényeges szerepet kaphat a térségi, területi és helyi iparpolitika, melynek fö célja egyrészt a térségen belül, másrészt a térségek közötti területi egyenlötlenségek mérséklése, és a térségi termelési potenciálok aktivizálása. Az iparpolitika legfontosabb céljai a területfejlesztési célokkal osszhangban mindezek következtében:

- térségi innovációs központok létrehozása, melyek egy-egy térségben az általános húzó szerepú vállalati struktúra megtestesítöi,

- olyan ipari infrastruktúra létesitése, amelyhez adott térség régi és új vállalatai egyaránt kapcsolódni tudnak, föként inkubátorházak, innovációs parkok, technológiai transzfer központok, információs hálózatok, térségi bankok rendszerei,

- az iparilag elmaradott térségek infrastrukturális fejlesztésével a gazdasági környezet kialakitása,

- a kormányzati támogatások összpontositása, koncentrálása a strukturális gondokkal küszködö, depressziós térségekre,

- a széthullott telephelyi szerkezetü vidéki ipar reintegrációjának elösegitése.

Észak-Dunántúl nagytérsége iparpolitikai koncepciója (NTK)

A szerkezetváltás - bár még nem ért véget teljesen - viszonylag dinamikusan folyt le a térségben. A gazdaságpolitika feladata e szerkezetváltást támogatni, elsősorban az infrastrukturális környezet fejlesztésével, melyek jelentős hányada üzleti alapon, koncessziókkal történik.

Mivel a koncentrált környezeti károsodások - a Duna eltereléséböl fakadó vízpótlás, ökológiai problémák a Szigetközben, a további Duna szakasz 
szennyezödése, a bányavidék karsztvíz elvezetéséböl, szint és hỏmérséklet süllyedésből fakadó problémák, a Tapolcai medencében és a Dunántúli középhegységben (Ajka, Várpalota, Tatabánya, Dorog) kialakult lég-, por- és sugárszennyeződés stb. - jelentős része is e térségben található, jelentös környezeti beruházásokra lesz szükség.

$\mathrm{Az}$ észak-dunántúli térség fejlesztésében figyelembe kell venni, hogy innováció hordozó a Bécs-Pozsony-Budapest gazdasági tengelyben, ezért Közép-Európa egyik fó gazdasági, üzleti centrumává válhat. A térség dinamikus gazdasága várhatóan a korábbinál és a jelenleginél nagyobb munkaerővonzást eredményez.

Mindezek következtében e térségben alapvetö kérdés a fenntartható fejlödés feltételeinek megteremtése. Ennek biztositására az Európai Uniohoz hasonlóan - a csatlakozás jegyében - az eltérö térségtípusokra eltérö eszközöket javasol:

- Ipari hanyatlás által érintett térségtípus Észak-Dunántúl területét tekintve csak Komárom-Esztergom megyében található. Az itteni nehézipari bázis szerkezeti átalakításában az állami részvételt nemzetközi források is támogatják, mert a környezeti szennyezettség is súlyosabb, mint más térségtípusokban.

- Környezeti szempontból kiemelt térségnek jelöli meg a bánya-rehabilitációs térségeket. Az állami beavatkozásra kijelölt térségek Komárom-Esztergom mellett Veszprém megye bányavidékei is.

- Határmenti térségtipusú Veszprém megyén kivül Észak-Dunántúl valamennyi megyéje. Közülük Györ-Moson-Sopron, Vas és Zala megye a gazdaságfejlesztési célokat szolgáló nemzetközi Phare-Interreg II. és a Phare CBC programok keretében közösen bonyolított fejlesztési programok aktív részesei.

- A gazdasági innováció pólusterületei közé sorolja az NTK Győrt és Sopront mint elsőrendủ centrumot, Komáromot, Tatabánya-Tata várospárt pedig másodrendủ innovációs pólusoknak. Lényegében csak a Bécs-Budapest tengelyt veszi figyelembe ${ }^{17}$ az északdunántúli térség területén.

- Tartós, magas munkanélküliségũ térséget kíván kezelni KomáromEsztergom és Veszprém megyékben.

- Vállalkozási övezetekbe sorolja azokat a térségeket, amelyekben kb. 1980 óta folyamatosan különleges gazdasági területeket (ipari parkok, inkubátorházak, vámszabad-területek, vámudvarok) hoztak létre, illetve fejlödtek ki. Unios értelemben a térségben két ilyen övezet megvalósulásának folyamata indult, az egyik Mosonmagyaróvár térségében, a másik Lenti-Lendva-Rédics térségében.

\subsection{A térség iparának erös és gyenge pontjai}

\section{Erôs pontok}

Erös pontok közül $a z$ elsö helyen említhetö az osztrák piac közelsége, a munkaerő szakképzettsége, a munkaerö bösége, a megyei termelési kapcsolatok és az innovátorok, vállalkozói ötletek sokasága.

A második helyre tehető az európai piac közelsége, valamint az üzem, a telephely elhelyezkedése, megközelithetősége. 
A harmadik helyen állnak a térségbeli termelési kapcsolatok már létezỏ egyes elemei, valamint az infrastruktúra városokban kiépített színvonala.

A negyedik helyen álló erös pont maga a térség ipara, melynek föbb alágazatai az élelmiszeripar, a gépipar, az alumíniumkohászat, a fémfeldolgozás, a vegyipar, az energiaipar és a textilipar. Ezen iparágak fö termékei versenyképesek, jól exportálhatók. A térség vállalatai igyekeznek általában a konjunktúrát is kihasználni, a legtöbben törekednek az anyag- és energiatakarékosságra, a környezetvédelemre, új termékek bevezetésére a meglévö technológián, igyekeznek bỏvíteni kapacitásaikat és föként dinamikus ágazatokhoz kapcsolódni.

\section{Gyenge pontok}

A sorrendiséget a kérdőivekben leadott szavazatok alapján határoztuk meg, egy egy tényezỏ sorrendiségét nagymértékben befolyásolhatja egy másik tényezővel való kölcsönhatása, ezért a sorrend nem tekinthetỏ objektívnek.

A térség leggyengébb pontjának vehető az, hogy a helyi és a térségi beszerzési piac szerepe jelenleg nem számottevő. A megkérdezett vállalatok ${ }^{18}$ beszerzési piacainak részesedésében 15\%-nál kisebb részarányt képvisel, míg a nyugat-európai országokból beszerzett termékek súlya mintegy 33-66\%-os arányok között változik.

Értékesítési piacukban viszont jelentős súlyú az országos és a térségbeli fogyasztói piac, mintegy átlagosan 33-66\%-os részarányú és csak a fennmaradó rész az exporthányad.

Fenti aránytalanság okai:

- a belföldön beszerezhetỏ áruk nagyobb anyagköltséget jelentenek (a nem megfelelő minöség miatt) a tovább-feldolgozó vállalatnál, mint az importból olcsóbban beszerezhetỏ áruk,

- a hazai beszerzésü termékek nem érik el az export által megkövetelt minőségi színvonalat,

- a szállitási határidők be nem tartása a hazai beszállítók részéről,

- a helyi és térségi piaci információk hiánya fejlesztésekről, beruházásokról, helyi vevőkről, beszállítókról, kapcsolati lehetőségekröl,

- a technológia alacsonyabb színvonala a külföldi tulajdonosú vállalatokhoz viszonyítva.

A helyi/megyei/térségbeli termelési kapcsolatok (kooperáció, bérmunka, bedolgozás stb.) gyengesége is szerepet játszik a magas importhányad tényében - a többi okon kívül - az ipar termelésében.

A következő gyenge pont az a tény, hogy kevés a kutatás-fejlesztéssel foglalkozó szakember, általában 1-5 fỏ alkalmazott végez saját fejlesztést, melyet többnyire a külföldről vásárolt licenc, technológia helyettesít. A megkérdezett vállaltok 2/3-a nem rendelkezett fejlesztő szakemberekkel, majdnem fele nem állt kapcsolatban semmilyen felsőoktatási intézménnyel vagy kutató intézettel. A kutató-fejlesztő szakembereket foglalkoztató cégek véleménye szerint a $\mathrm{K}+\mathrm{F}$ tevékenységgel foglalkoztatható szakemberek sem mennyiségben, sem minöségben nem állnak rendelkezésre.

A harmadik helyen áll az, hogy a vállalatok fejlesztési stratégiájukban nem számolnak a nyersanyagok másodlagos feldolgozásával (pl. hulladékfeldolgozás), sem $\mathrm{K}+\mathrm{F}$ tevékenységgel. Nem konjunktúrára épitö, hanem azt csak eszközként 
felhasználó, valódi jövőépitő stratégióval a megkérdezett vállalatoknak csak egyötöde rendelkezett.

A negyedik helyet foglalja el a munkaerő bősége és nem megfelelö szakképzettsége, a térségbeli pénzügyi szolgáltatások, az üzem, telephely megkőzelíthetósége. (A községek megközelíthetösége általában nem azonos színvonalú a városokéval - közút-, vasút-, légi- és vízi út.)

Mivel a rendelkezésre álló munkaerő egy részének szakképzettsége erös pont is, a nagy létszámú, bőségesen rendelkezésre álló csoportja feltehetően alacsony szakképzettségú vagy alig iskolázott. Az iskolázottság és szakképzettség megszerzése annyiban válhatna ipari feladattá is, hogy az ipar kijelöli a képzési és átképzési irányokat és célokat e kör valamint a magasan képzett, ám struktúrájában nem megfelelö kör számára.

A helyi/megyei/térségbeli pénzügyi szolgáltatások színvonalának a gyenge pontokhoz sorolása feltehetöen a megkérdezett vállalati körben kamatkondíciókkal való elégedetlenséget takar, ezért annak javitása kormányzati kompetencia.

A sorrendben az ötödik gyenge pont az, hogy az innovátorok mozgástere nem megfelelő (vállalkozói ơtletekben ugyanis nincs hiány). Tehát a magasan képzett réteg, amelyik $\mathrm{K}+\mathrm{F}$ tevékenységre alkalmas, nem olyan jellegú ơtletekkel áll elö, melyre a jelenlegi licencet és technológiát vásárló ipari vállalatoknak szüksége van, illetỏleg a külfơldi tulajdonosú vállalatok a technológiát magukkal hozzák az anyavállalattól, melyre az átképzés a vállalati keretek között meg is történik. A rendelkezésre álló munkaerő egy része tehát jelenlegi képzettségi struktúrájában nem foglalkoztatható.

6.3. Nagy és középvállalatok kötődése szék- és telephelyeik térségéhez, településeikhez

A vizsgálatainkból az a következtetés vonható le, hogy e két vállalti nagyságkategória vállalatainak adott térséghez, településhez való kötődése, nagymértékben befolyásolhatja a térség fejlödését, fejlesztését és kockázati elemet jelent annak ipari szerkezetében

A megkérdezett vállalatok alapvetően három csoportba sorolhatók gazdálkodásuk alapján:

- azon vállalatok, amelyeknek a felvevő piacai nagyrészt vagy egészében külfơldön találhatók, de erősen függnek egy országtól,

- azon vállalatok, amelyeknek a felvevő piacai több országban találhatók, közöttük a hazai piacon nem kötődnek szorosan sem a régióhoz, sem a telephely településéhez,

- azon vállalatok, amelyeknek a felvevő piacai több országban találhatók, de erösen kötődnek a hazai piachoz országosan és lokálisan is, ám a lokális kötődése elsősorban tradicionális alapokon nyugszik.

Az egyes csoportok véleménye - nyilvánvalóan viselkedésük is - eltérő néhány nagyon fontos kérdésben, így a beszerzési piacaikat tekintve, a kormányzat ipari átalakulást segítő szabályozási rendszerével kapcsolatban, a környezetvédelmi beruházásokrỏl, az önkormányzati kapcsolataikról, és az öket érintö vagy éppen hidegen hagyó Európai Uniós tagságról. 
Az első csoportot az adott helyhez csak a szakképzett munkaerő és a termelési kultúra köti, az önkormányzati kapcsolatokat terhesnek érzik. Beszerzési piacuk teljes egészében külföldi, ezért tulajdonképpen hasznos lesz számukra az EU-s tagság, mert a vámokat megszünteti. Az ott érvényes import norma, mely szerint egy országból az alapanyag 60\%-a származhat, lényegében nem érinti őket, mert a vállalati lánc behálózza a világ nagy részét. A környezetvédelmi előírásokat esetenként túlzottnak tartják, sőt szerintük magasabbak a magyar normák az EU-s normáknál. Rendszeresen környezetvédelmi bírságot fizetnek, melynek nagyságrendje (50-100 EFt/év) nem jelentős költségvetésükben. Azonban ilyen jellegủ beruházási kötelezettség a magas beruházási költségek miatt súlyosan érintené öket, megfontolnák a térség elhagyását. A vállalkozás részvényeinek általában a dolgozók semmilyen hányadban nem tulajdonosai, vezetői, a menedzsment is csak elenyészó hányadban.

A második és harmadik csoportot a belföldi piac köti az országhoz, különbség alapvetően a kötődés tradicionális jellege és erőssége kỏzött van közöttük. A harmadik csoport vállalatainak a helyi önkormányzatokkal való kapcsolata nem korlátozódik csak helyi adó kapcsolatokra, hanem jelentős segítői, adott esetben részt vállaló megvalósítói egy-egy településfejlesztési akciónak, sőt települési szociális jellegü szolgáltatásoknak is.

A második csoportot élénken foglalkoztatja, mire használja az önkormányzat az általa befizetett több százmilliós helyi adót, de erről információkat nem mindig kapnak.

Mindkét csoport fontosnak tartja a környezetvédelmet. Eltérö intenzitással, ám igyekeznek beruházásaik folyamán egyrészt környezetkímélő technológiát megvalósítani, másrészt speciálisan ilyen beruházásokat tenni annak ellenére, hogy ma a környezetvédelmet szolgáló berendezések rendkivül drágák. Mivel általában elég speciális berendezésekröl van szó, legtöbbjüket csak külföldröl lehet beszerezni, ezért a vám is drágítja őket. E két csoportban fellelhető a vállalatok részvényeinek dolgozói tulajdonlása is kisebb-nagyobb mértékben, sőt a jelenleginél nagyobb mértékü tulajdonrész saját vállalati birtokban tartását látják célszerünek.

\subsection{Kormányzati gazdaságfejlesztési eszközök}

A Kormányzat ipari átalakulást támogató tevékenysége

A Központi Kormányzat az 1989-töl napjainkig terjedő időszakban sokféle módon támogatta az ipari szerkezetváltás folyamatát. Ezek közül kiemelhető:

- az inkubátorházak, ipari parkok létesítése,

- a különleges gazdasági övezetek, vámszabad-területek létrehozása,

- a kockázati tőketársaságok alapításában való részvétel,

- részleges adóskonszolidáció végrehajtása,

- az elkủlönített állami pénzalapok múködtetése

- adókedvezmények általi támogatás. 
A kormányzat szerkezetátalakulást célzó pénzügyi eszközei

a:/ Elkülönitett állami pénzalapok

Az elkủlönített állami pénzalapok a felhasználás alapján három nagy csoportra oszthatók:

- Önkormányzatok által igényelt alapok,

- nem területi kiegyenlítést szolgáló alapok igénybevétele,

- területi kiegyenlítést szolgáló alapok igénybevétele.

Az elsó csoportba valamennyi alap beletartozik, a projektektől tartalmától és résztvevőitől függően. A második csoportba csak azok az alapok (idegenforgalmi, kereskedelemfejlesztési, befektetés-ösztönzési, központi müszaki fejlesztési) tartoznak, amelyek a gazdaság fejlesztését szolgálták elsỏsorban, míg a harmadik csoportba_tartozók (foglalkoztatási, területfejlesztési, központi környezetvédelmi) a területi kiegyenlítést, a különbségek mérséklését egyrészt adott térségen belül, másrészt térségek között. (Rechnitzer 1996)

Kifejezetten csak az ipari átalakulást, szerkezetváltást a befektetés-ösztönzési és a kereskedelemfejlesztési alapok segítették, illetve 1995-től a gazdaságfejlesztési alap.

\section{TÁBLÁZAT}

Az elkülönített állami pénzalapok támogatásai 1990-1994 között

Support grants from the separate state funds in 1990-1994

\begin{tabular}{|l|c|c|c|c|c|}
\hline \multicolumn{1}{|c|}{ Megye } & $\begin{array}{c}\text { Befektetés } \\
\text { osztonzési }\end{array}$ & $\begin{array}{c}\text { Kereskedelem } \\
\text { fejl. i }\end{array}$ & Nem kiegyenlítö & Kiegyenlítö & Önkormányzati \\
\hline & & & \multicolumn{2}{|c|}{ fejlesztési igénybevétel össz. Ft/fö } \\
\hline Györ-M-S & 553 & 191 & 1630.4 & 2794,0 & 1033,0 \\
\hline Vas & 1260 & 109 & 1697,6 & 4207,6 & 428,0 \\
\hline Veszprém & 522 & 179 & 1999,1 & 3638,0 & 501 \\
\hline Zala & 197 & 111 & 1071,3 & 3533,3 & 902 \\
\hline ÉNY-Dunántúl & & & & & \\
\hline Fejér & & & & & \\
\hline Kom.-Esztergom & 1223 & n. a. & 2271,1 & 4990,4 & \\
\hline É-Dunántúl & & & & & \\
\hline Vidék ósszesen & 333 & 109 & 1083,5 & n. a. & 660,0 \\
\hline Ország osszesen & 292,0 & n. a. & n. a & n. a. & 1060,0 \\
\hline
\end{tabular}

Forrás: Minisztériumok adatközlése alapján Rechnitzer János számítása

A befektetés-ösztönzési alapból nyújtott támogatások nagysága általában a teljes beruházási költség mintegy 3-10\%-át tette ki. Alapvetỏen a vállalkozások múködtetéséhez, vagy a saját területén, vagy a telekhatáron túl is szükséges, kapcsolódó infrastrukturális fejlesztésekre lehetett megpályázni. Általában koncentráltan a nagyvállalati kỏr jutott e támogatásfajtához.

A térségben elnyert kereskedelemfejlesztési pályázatok céljai a következök voltak:

- szakmai kiállítások és vásárok megrendezése kül- és belföldön,

- üzletemberi találkozók szervezése, 
- reklámok készítése,

- termékkatalógusok,

- minőségbiztositás,

- minta darab legyártása,

- piackutatási tanulmányok készítése,

- az ország hírnevét népszerüsítő termékkiállitások,

- szabadalmaztatás,

- vámveszteségek téritése a kormányhatározati körben.

A megitélt támogatásokhoz képest a tẻnyleges pénzügyi teljesités (pénzlehívás) általában $60-70 \%$-os ${ }^{19}$ volt. A mintegy egyharmadnyi megtakarításban (?) fökẻnt az EXPO elmaradásának és a szerződések felbontásának volt meghatározó szerepe.

\section{b./ Nemzetközi pénzintézetek által folyósitott beruházási célt szolgáló hitelforrások}

Alapvetỏen három bank finanszírozott a gazdaságpolitikához kapcsolódó beruházási projekteket 1991-1994 között:

- a Világbank-csoport részeként az IFC magánszektorbeli projektekhez nyújtott segítséget,

- az EBRD (Európai Újjáépítési és Fejlesztési Bank) kizárólag projekteket,

- az EIB (Európai Beruházási Bank) szintén projekteket finanszírozott.

E pénzintézetek müködésében jelentős eltérések ${ }^{20}$ vannak aszerint, hogy a gazdaság szereplőinek vagy a kormányzat projektjeinek finanszírozását végzik.

Az EBRD hitelkihelyezéseinek megoszlását a 17. táblázat mutatja:

\section{TÁBLÁZAT}

Az EBRD kihelyezéseinek megoszlása, 1991-1994

Breakdown of the placements of the EBRD, 1991-1994

\begin{tabular}{|l|c|c|}
\hline \multicolumn{1}{|c|}{ Térség } & Kihelyezett tőke (millió ECU) & Részaránya \% \\
\hline Nyugat-Magyarország & 176,6 & 24 \\
\hline Dél-Magyarország & 59,6 & 8 \\
\hline Kelet-Magyarország & 8,8 & 1 \\
\hline Térségre nem bontható* & 354,8 & 46 \\
\hline Vidék összesen & 599,8 & 80 \\
\hline Budapest & 145,8 & 20 \\
\hline Ország ósszesen & 745,6 & 100 \\
\hline
\end{tabular}

* Benne található az OKHB, az MHB, az OTP és a BB által továbbadott mezôgazdasági szerkezetátalakító hitelkeret is

Forrás: Bod Péter Ákos: Területfejlesztési problémáink és a nemzetközi pénzintézetek. 1995

A nagyfokú koncentráció mellett a nyugat-magyarországi nagy részesedés kis számú, de nagy összegủ tranzakciót takar, mint pl. a szentgotthárdi OPEL gyárnak nyújtott 66 millió ECU-s hitel, vagy az M1-M5-ös autópálya építéséhez nyújtott 100 millió ECU-nél nagyobb hitel. A dél- és kelet magyarországi hitelek egy-egy projekthez kapcsolódtak, olaj-, gáz- és vegyipari beruházásokhoz (zsanai föld alatti gáztároló, tiszaúj városi koromgyár). 
Az IFC hitelei nagyságrenđdel kisebbek, mint az EBRD hitelei, ágazati megoszlásukat a 18. táblázat mutatja:

\section{TÁBLÁZAT}

Az IFC kihelyezései, 1994

Placements by the IFC, 1994

\begin{tabular}{|l|c|c|}
\hline \multicolumn{1}{|c|}{ Ágazat } & Hitel (millió dollár) & Részarány \%-a \\
\hline Távközlés & 41 & 30 \\
\hline Pénz-, tókepiac & 40 & 30 \\
\hline Feldolgozóipar & 22 & 16 \\
\hline Mezögazdaság & 16 & 12 \\
\hline Vegyipar & 16 & 12 \\
\hline Ország ósszesen & 135 & 100 \\
\hline
\end{tabular}

Forrás: Bod Péter Ákos: Területfejlesztési problémảink és a nemzetközi pénzintézetek. 1995

A hitelek nagy részét (30\%) infrastruktúra fejlesztésére és pénz és tỏkepiaci fejlesztésekre (30\%) adták ki. A feldolgozóipar és vegyipar együtt a hitelek 28\%-át, a mezögazdaság csak $12 \%$-ot kapott.

Az EIB összesen 27 millió ECU értékủ hitelt bocsátott a valamennyi megyét érintő energiaprogram (hangfrekvenciás központi vezérlés) fejlesztésére, valamint egyes hátrányos helyzetủ megyék több projektjére (hídrehabilitáció: Borsod, Nógrád, Baranya, Szabolcs; telefonközpontok: Borsod, Szabolcs).

Valamennyi bank elsösorban azokat a projekteket finanszirozta, amelyek üzleti terveik alapján üzleti szempontból életképesnek, pénzügyileg megtérülőnek és kifizetôdőnek bizonyultak előkészítésük alapján. (Bod 1995)

\subsection{Konzisztencia az egyes szintek iparpolitikai koncepciói között}

$\mathrm{Az}$ egyes térségekre és térségtípusokra vonatkozóan valamennyi lényeges iparpolitikai elem konzisztensnek tünik a koncepció szintjén. Így:

- az elérhetỏ támogatási formákat (elkülönített állami pénzalapok, adókedvezmények, MVA-beli kedvezményes hitelek, kamattámogatások, kockázati tókefinanszírozási módok, Phare és OECD támogatások),

- a szerkezet átalakítást, a fejlỏdést segítő intézmények telepítését (inkubátorházak, ipari parkok, innovációs központok, különleges gazdasági, vállalkozói övezetek, vámszabad-területek, logisztikai központok), és

- a helyi és térségi hatalom, az önkormányzatok lojalitását tekintve.

Nincs konzisztencia jelen pillanatban az iparpolitika (a kapcsolódó $\mathrm{K}+\mathrm{F}$ tevékenységgel egyưtt értelmezve) és a pénzügyi szabályozás makroszintjei között a felmérések értelmében az alábbi elemekben:

- vállalkozások redisztribúciós szabályozása, túladóztatás,

- a forint árfolyam-politika,

- a beruházások hitelforrásainak kamatpolitikája,

- az exportösztönzés és importkorlátozás rendszere,

- a $\mathrm{K}+\mathrm{F}$ politika valamennyi szintje (oktatás, kutatás, termelés). 
A konzisztencia hiányát a vállalkozások ugyanúgy kẻnytelenek elszenvedni, mint az önkormányzatok saját gazdálkodásukban. Amennyiben a konzisztencia nem teremthető meg makrogazdasági szinten, akkor törekedni kellene lehetőségét megteremteni térségi szinten. Ez persze rendkivül nagyfokú önállóságot jelent az egyes térségek részére, nyilvánvalóan éppen a makrogazdasági szintủ konzisztencia hiányból adódóan a makrogazdasági szabályozáshoz képest más jellegú szabályozási rendszert. Talán úgy oldható meg a legegyszerủbben, ha adott térség teljes egészében különleges vállalkozói övezetnek minősül, legalábbis a nemzetgazdaság szintjétöl való formális elkülönülés tekintetében. Mint ilyen övezet, a vállalkozások tevékenységét illetöen javasolható egyik irányítási eszközként a térség szintjẻn értelmezett konjunktúrapolitika eszközrendszerének alkalmazási megfontolása. A makro szint a különböző térségek folyamatait könnyebben és átláthatóbban irányíthatja és hangolhatja össze, mint a 19 különbözö megyéét.

Alkalmazott konjunktúra kutatás esetén a térség gazdaságának mind a négy folyamatát, a jövedelemképzödést, a termelést, a fogyasztást és a megtakaritásokét vizsgálni kell a gazdaság tágan értelmezett adottságait (demográfiai folyamatok, a technikai fejlödés folyamata) is figyelembe véve. Könnyen belátható az, hogy a konjunktúrák mozgáselemei (a gazdasági fejlödés alapiránya, az idényhez kötött változások, a ciklusos hullámzások (a konjunktúra), és a maradék hullámzások) egy történelmi-földrajzi és gazdasági szempontból egységként kezelhetö térség esetében valószínüleg más jellegzetességekkel fognak rendelkezni (hiszen még az ágazatok ciklusjegyei is eltérőek), ezért az alkalmazandó konjunktúrapolitikai eszközök ${ }^{21}$ sem lehetnek azonosak teljesen, bár jelenleg csak az országos szint létezik mind a vizsgálatokban, mind a gazdaságirányítás alkalmazott konjunktúrapolitikai eszközeiben.

A konjunktúraciklus lényegében a tartós tỏkejavak termelésének ingadozása, ezért nagyon fontos az egész tőkeképződés ${ }^{22}$ folyamatának mindkét ága is, azaz a megtakarítások és a beruházások alakulása a térség egyes iparảgait tekintve.

A konjunktúra vizsgálatok, elemzések célja az kell legyen, hogy olyan konjunktúrapolitikát lehessen megfogalmazni adott térség esetében is, mely az alkalmazott eszközök segítségével képes a konjunktúrahullámzások szélsőségeinek tompitására, vagyis a válság enyhítésére és a fellendülés tủlhajtásainak megakadályozására, azaz a gazdaság egẻszének egyensúlyi állapota közelítéseire a térség szintjén. Országosan viszont éppen a ciklusok idöbeni elkülönülése (elkülönítése) lehetőséget teremtene az ország szintjén is a cikluskilengések csökkentésére.

\section{Mi legyen az iparfejlesztés, stratégia centruma?}

Az eddigiek alapján a következő stratégiai célok javasolhatók az irányítás térségi és helyi szintjeire egyaránt, azzal a lényeges különbséggel, hogy a térségi szint a stratégiai jelleget erősítse múködésében, mert az operatív tevékenységet nyugodtan a helyi szint szakembereire bizhatja. De a helyi szint viszont vegye ki az operatív teendőket a térségi kézbỏl, és a stratégia megalkotásából se maradjon ki. Ha szilkséges "csábitsa el" helyi szintre a térség szakembereit. A térség pedig adja oda 
"hozományként" elcsábitott szakemberei bérkeretét is a helyi szintnek. A fö célok tehát a következök lehetnek:

- a kis és középvállalatok pénzügyi, müködési, technológiai feltételeinek javitása, ezáltal verseny képességük növelése,

- a magas szintủ szellemi munkára épülö dinamikus iparágak fejlesztése,

- a szellemi erőforrások bövítése (felsőoktatás, kutatás-fejlesztés)

- a külföldi múködő tőke fogadási feltételeinek javítása,

- a képzési rendszer igazitása a magas fokú szellemi munkára épülő ipar igényeihez,

- infrastruktúra fejlesztése,

- az ipar regionális szintú irányítása, benne a regionális konjunktúrapolitika eszközeinek összehangolt alkalmazása a makroszint konzisztenciảjảnak megteremtésével,

- ipari klaszterek kialakítása.

A pénzügyi szolgáltatások illetve a térségi kapcsolatrendszer javítása érdekében négy fontos makro gazdaságpolitikai változtatás feltétlenül fontos lenne a makro szinten, mely a térségi irányitás kerete és ne kerékkötője legyen:

- beruházási hitelek kamatpolitikảjának csökkentése,

- importkiváltás ösztönzése, mely nem azonos az egyoldalú importkorlátozással, hanem pl. rafinált minöségi és környezetvédelmi elöirások érvényesítése,

- a forintárfolyam értékelő politika változtatása a jelenlegi iparátalakulási folyamatokban a technikai felzárkózást segítő szándék preferálásával,

- a $\mathrm{K}+\mathrm{F}$ tevékenység valamennyi szintjének (oktatás, kutatás, termelés) támogatása az Európai Közösség országaiban alkalmazott arányokkal (a GDP \%-ában).

\subsection{Ipari terek, klaszterek Észak-Dunántúlon}

A térség tulajdonában átalakult, térben átrendezödött és szerkezetében átsúlyozódott iparágai alapján az alábbi klaszterek ${ }^{23}$ alakíthatók ki az észak-dunántúli térségben:

Élelmiszeripari klaszter, melynek lehetséges elemei (a jelenlegi termékstruktúra alapján):

- élelmiszergazdasági kutatás, fejlesztés, tanácsadás,

- mezögazdasági termelés (kis- és közepes méretú, egyéni és társas vállalkozások),

- élelmiszeripari feldolgozás,

- felvásárlási, ellátási rendszer (integrációs szervezet, mely a végtermék előallítója is lehet),

- értékesítési, beszerzési szervezet, amelyen belül a külpiaci értékesités kiemelendő, ez sem igényel feltétlen különálló szervezetet, kapcsolódhat a végtermék elóállítójához,

- tejtermelés és tejfeldolgozás

- a húsipar, 
- a takarmány-feldolgozás,

- a zöldség- gyümölcs feldolgozásban és a tartósító és konzervipar, hütőipar,

- az üdítőitalok, ásvảnyvizek és szesztartalmú italok gyártása. (Hrubi 1994)

Fö területei: Györ-Moson-Sopron, Vas, Zala és Komárom-Esztergom megyék a térségben.

A klaszter termékeinek jelenlegi (a keleti piacok gazdasági helyzetének stabilizálódásáig) piacát a nyugat-európai országok jelenthetik, közülük is elsősorban Ausztria, Németország, Olaszország, Hollandia. Hosszú távon talán Szlovákia, valamint a térség területe.

Valamennyi fenti terület termékei vertikumának hagyományai vannak a térségben. Az egyes kapcsolatok (kis- és középvállalkozások) és fejlesztési szükségletek (értékesítö-beszerző szervezeti, gyártmány és technológia, piaci alkalmazkodás) feltérképezése a biztos stratégia megfogalmazásához elengedhetetlen, hiszen a korábbi állami tulajdonú struktúra a térségben teljesen átalakult. Az egyes kapcsolati pontok hiánya nagymértékben befolyásolja az egyes termékek elỏállításának importszükségletét. Ugyanakkor megfigyelhető pl. a gépiparban a külföldi technológiával gyártó vertikumok, beszállítói láncok kialakulása. (Hamvas 1995)

Az átalakulással, tulajdonos váltással kapcsolatosan persze nagy kérdésköre az ipar egészének az, hogy sikerül-e és mennyi idő igénybevételével a tisztán magyar tulajdonosokból, vagy többségükben magyar tulajdonosokból álló vállalatok technikai felzárkózása a dinamikus vállalatok beszállítói igényeihez, vagy másként, megtalálják e azokat a piaci réseket mind a térségben, mind azon kívül, melyek létük fennmaradását biztosítják termékeik megvásárlásával.

Feldolgozó-ipari klaszter, melynek lehetséges elemei:

- kohászat és fémfeldolgozás, alumínium kohászat

- energiaipar

- gépipar, gépi berendezések gyártása, villamos ipari gépek gyártása

- környezetvédelmi berendezések gyártása

- finomvegyészet

- kerámiaszál-gyártás

- könnyüipar (textil, konfekció, kesztyủ és múbörgyártás)

- fafeldolgozás

A térség valamennyi megyéje e klaszterben a neki megfelelő iparágban helyet kaphatna.

Szolgáltató tevékenységek klasztere, melynek lehetséges elemei:

- oktatási, szakképzési szolgáltatások

- kutatási és fejlesztési szolgáltatások

- pénzügyi-, befektetỏi- kereskedelmi és jogi szolgáltatások

- idegenforgalmi szolgáltatások

- települési infrastukturális szolgáltatások

A térség valamennyi megyéje e klaszterben is a neki megfelelő szolgáltatási ágban helyet kaphatna. 
Kitermelö ipari klaszter lehetséges eleme:

- bányászat (Veszprém, Zala, Komárom-Esztergom)

E klaszter kialakítása nagy körültekintést igényel, hiszen a bányászat szerepe országos viszonylatban csökken.

Az első és második klaszter-elemeiben jelenleg magas az importhányad, mely magas anyagköltséget eredményez. Ezért törekedni kellene egyrészt a térségi kapcsolatokból származó elönyök kihasználására, másrészt a feldolgozó részére az import minöség biztosítására. Feltétele a magas színvonalú szakmai ismeretekre és kutatást-fejlesztés igényességre épülő technológia.

Talán érzékelhetö az, hogy az ipari szerkezet-átalakítás egy olyan viszonylag hosszú folyamat, mely magában foglalja az Európai Unióhoz való csatlakozással járó "váltó-átállítás" nehézségeit, problémáit is. Összességében elmondható, hogy a bonyolult folyamatok az észak-dunántúli térségben és talán országosan is a nagyrészt külföldi magántulajdonú nagyvállalatok magyarországi megerősödését, tỏkekoncentrációját eredményezte, számos újonnan létesült kis- és középvállalkozás csödjével párhuzamosan. Ha azonban az utóbbi években a jegyzett tőkében bekövetkezett külföldi tulajdon részesedések arányának csökkenése a spekulációs tőke kivonulását takarja - vagyis a térségidegen, a térséghez nem kötỏdő tőkéét akkor egy olyan pozitív irányú folyamat kezdödött el, mely feltehetően a térség stabil életképességét, fejlődését biztosító ipari, gazdasági körzetekben ölt majd testet.

\section{Jegyzetek}

${ }^{1}$ Szakmai és politikai viták jelenleg is folynak a piacgazdaság jellegéről, azaz alapvetően a nyugateurópai típusủ szociális piacgazdaság, vagy az amerikai típusú liberális piacgazdaság felépítésének útján járjon-e Magyarország. A vitában sokan utalnak arra, hogy alapvetöen tiszta liberális piacgazdaság a multinacionális cégek illetöleg a létezó monopolhelyzetek miatt nemigen létezik.

2 Lásd: 1990. évi LXV. tv. az önkormányzatokról, benne feladataikról

${ }^{3}$ Rechnitzer János: A területi munkamegosztás és az egyik vizsgálati módszere Baranya megye példáján. In: Az igazgatás és a gazdaság teruleti rendszere. Pécs. 1981. MTA DTI Kozzlemények 28.

4 A ráta értéke valóságosan nagyobb lehet, hiszen a regisztráltak köréböl kikerülö munkanélküliek számáról nincs nyilvántartás. Egyes szakértói becslések szerint a nyilvántartottnak mintegy két- két és félszerese a tényleges ráta.

${ }^{5}$ A kủlönféle gazdasági szervezetek az 1988. évi gazdasági társaságokról szóló VI. törvényt kővetóen kezdtek el megalakulni. Az 1991-ig tartó időszak a kezdeti évek időszaka, mig 1991-től számíthatjuk a fel futási idószakot.

${ }^{6}$ Közơttük az alábbi nagyobb cégek találhatók, nem teljes kơrủ felsorolásban: Györ-Moson-Sopron: Leier, Audi, Candy, Arlington, Calida

Vas: General Motors Hungary (Opel), Vossen

Veszprém: Nicolor, Goldburg , Beurer-Hungária Kft., Hammerstein Kft., ITT Automotive Kft.,

Komárom-Eszetergom: Suzuki, Jung Hungária, FOTEX Plastic Kft., A.M.P. Kft., Koloman-Handler Kft.,

Fejér: Ford Hungaria Kft., Loranger Kft, Phillips Video Magyarország Kft., Shell Gas Hungary Kft.

7 Magyarországon az Ipari Parkok Egyesülete programcélkitúzése e tekintetben "...Olyan normativ kritériumok (standardok) kidolgozását kezdeményeztük, melyek teljesitését vállalva a vállalkozó mentesül a hosszadalmas engedélyezési eljárás alól (épitészeti, tủzvédelmi, környezetvédelmi, áram-, vizfogyasztási, cégbejegyzési, adóbejelentés és bevallás, TB. regisztrálás, hitelưgyintézés, idegenrendészeti eljárás stb. elóirások). Gyakorlatilag azt kellene elérni, hogy egy helyen (egy ablaknál) megoldható legyen a vállalkozás indítása. (Az angliai Corbyban a letelepedés idóigénye 24 óra!) " In: Beszámoló az Ipari Parkok Egyesưlet tevékenységéröl. Kézirat. 6. old. 
8 Ilyen települési tényezỏk fontossági sorrendben: új ismeretek (technológia, betanulás, megújítási képesség), a szakképzési intézmények képzési irányai, programjai, telefonnal való ellátottság színvonala, helyi adók mértéke, helyi, térségi lakosság fogyasztása, adott szakirányra rendelkezésre álló munkaerö, valamint képzett munkaeró, munkakultúra és termelési tapasztalatok, új beruhäzások infrastrukturális fogadási feltétele, $\mathrm{K}+\mathrm{F}$ információkat kináló szervezetek, a kömyezet minósége, helyi környezetvédelmi elöírások, helyi adókedvezmények, helyi építésügyi szabályozás (rendezési tervek), $\mathrm{K}+\mathrm{F}$ intézmények, közbiztonság, a föváros elérhetősége, helyi, térségi konkurencia, beruházások pénzügyi támogatása, lakásárak

9 Rechnitzer-Horváth-Sipák-Máthé (1993) Az ónkormányzatok szerepe és lehetőségei a regionális ipari fejlesztéspolitikák kidolgozásában, megvalósításában. Zárótanulmány. MTA RKK ÉDO, Győr Rechnitzer-Döry (1995) A kis és közepes vállalkozók árbevétele a területfejlesztésben, igényeik bemutatása a Gyỏrben létrehozandó inkubátorházzal szemben. Zárótanulmány. MTA RKK NYUTI, Györ Rechnitzer-Döry (1996) A regionális iparpolitika a megyei területfejlesztésben. Kutatási összefoglaló. MTA RKK NYUTI, Gyơr

${ }^{10}$ Kérdöivvel megkérdezett régióbeli 38 vállalat válaszai alapján, mely készült a KTM megbízásából. A teljes kérdỏiv értékelés megtalálható: Régió-ÉNY-Dunántúl területfejlesztési stratégiája II. kötet. 1995. MTA RKK NYUTI. Györ. (Máthé 1995)

${ }^{1 "}$ Kérdőives felmérés, készult a KTM megbízásából. A teljes kérdőiv értékelés megtalálható: RégióÉNY-Dunántúl területfejlesztési stratégiája II. kötet. 1995. MTA RKK NYUTI. Györ. (Szörényiné 1995)

${ }^{12}$ Megkérdezett formák: inkubátorház, innovációs központ, vállalkozói zóna, vámszabadterület, vállalkozásfejlesztési ügynökség, ipari park, kockázati tőketársaság, regionális fejlesztési társaság, regionális fejlesztési ügynökség, regionális fejlesztési tanács, ipari tevékenység fejlesztésére szervezett profitérdekeltségü vagy nonprofit érdekeltségü gazdasági szervezet

${ }^{13}$ A megállapítás nemcsak az iparra, hanem a mezőgazdaságra is vonatkozott, a válaszadók példaként felhozták az osztrák mezögazdasági termékek adómentességét és egyéb kedvezmények nyüjtásának osztrák gyakorlatát.

${ }^{14}$ 1996. október l-étöl az új vámtörvény megszunteti öket 180 napos türelmi idövel. Szerepüket a vámìgynökségek veszik át. (Világgazdaság, 1996)

${ }^{15}$ A teljes kérdöiv értékelés megtalálható: Régió-ÉNY-Dunántúl teruletfejlesztési stratégiája II. kötet. I995. MTA RKK NYUTI. Györ (Szörényiné 1995)

${ }^{16}$ Bövebben lásd: KORTEN D. C., (I995) Tökés társaságok világuralma Kapu, Budapest

${ }^{17}$ Hiányzik a térségben Székesfehérvár, Veszprém, Szombathely és Mosonmagyaróvár m̧eg̣eldlése, akár úgy is, mint másodrendü kutatási és oktatási centrumok, mert jelenleg is rendelkónek e városok nemzetkőzileg is elismert ilyen jellegú tevékenységgel. A "kihagyás" visszafejlesztést jelent !?

1838 megkérdezett vállalat válaszai alapján

${ }^{19}$ Minisztériumi adatközlés alapján saját számitás

${ }^{20}$ Lásd: Mistry, P. S.: Multilateral Developments Banks. Fondad, The Hague. 1995. (Bod 1995)

${ }^{21}$ Általánosan felsorolva ezek: kamatláb-politika (diszkontpolitika, jegybank politika, devizapolitika,), nyíltpiaci müveletek (értékpapírok nyílt piacon való vétele és eladása), kủlfơldi kölcsönpolitika (tőkekivitel és tökebehozatal), vállalkozáspolitika, konjunktúra-elörejelzés. Az egyes ciklusbeli szakaszokhoz más-más mixelt eszközrendszer tartozik.

${ }^{22}$ Alapvetóen négy forrása van: a lakossági takaréktöke képzödés, a vállalkozói töke képzödés, a közbevételekből történö tökeképzödés és a hitelpolitikai tökeképződés.

${ }^{23}$ Klaszter: a regionális munkamegosztási és kooperációs rendszer csomópontjai, amelyek a regionális fejlesztési stratégia alapelemeit adják. Olyan sürüsodési pontok a térség gazdaságában, melyek egyrészt ágazati és funkcionális kötödésben, egyfajta sajátos vertikális kapcsolatrendszerben álló gazdasági egységek láncolatát jelentik versenyképes végtermék vagy szolgáltatás előállitása, jövedelmező termelési folyamat révén, elsódlegesen a térség belső erőforrásaira támaszkodva és azt hasznosítva, másrészt a térség gazdasági-szolgáltató egységei között egy olyan kapcsolati háló, mely biztosítja a piac kőzvetlen hatásközvetítését a közős érdek alapján álló információszolgáltatást és a piaci impulzusokra történő reakciót egyaránt. E klaszterek elsődlegesek, de nem kizárólagosak a térség fejlödésẻben. Hisz a piaci viszonyok alapján kiépülö regionális munkamegosztás egy folyamat eredménye. (Hrubi I994) 


\section{Irodalom}

Barta Gy. (1991) Az ipar szerepe a szocialista gazdaság- és területfejlesztési politikában. 1I. SpanyolMagyar Szeminárium a területi egyenlốtlenségekröl. MTA RKK Pécs. 1991. 219-234. o.

Bod P. Á. (1995) Területfejlesztési problémáink és a nemzetkőzi pénzintézetek. Külgazdaság 1995 5461.0.

Dr. Kiss É. (1995) A fövárosi és a Pest megyei ipar szervezeti megújulása. Statisztikai Szemle 1995/január. 59-73. o.

Enyedi Gy. (1995) Bécs-Pozsony-Györ gazdasági háromszög együttmüködési lehetőségei és jővőbeli perspektivái. Kutatási jelentés. Budapest.

Enyedi Gy. (1995) Új regionális folyamatok a posztszocialista Kelet-Közép-Európában. Info és Társadalomtudomåny 1995/29. sz. 59-67. o.

Hamvas A. (1995) A piramis titka. Autóipari változások itthon és a nagyvilágban. Figyelö 1995. szeptember 7. 15-16. o.

Hoványi G. (1995) Tájkép csata után - avagy magyar iparvállalatok válságmenedzselése. In: Attekintés a magyar gazdaság strukturális folyamatairól. Résztanulmányok. MTA Ipar- és VállalatgazdaságKutató Intézet. Budapest 1995. február. 121-141. o.

Máthé M. (1993) Az önkormányzatok és a vállalkozások. In: Rechnitzer J.-Sipák T. (ed.): Az önkormányzatok szerepe és lehetöségei a regionális ipari fejlesztéspolitikák kidolgozásában. megvalósitásában. MTA RKK Észak-Dunántúli Osztály, Györ

Máthé M. (1994) A területhasználat ára, területérték adó. MTA RKK Észak-Dunántúli Osztály, Györ

Máthé M. (1995) A privatizáció rendszere a központi költségvetési szerveknél és az ơnkormányzatoknál. MTA RKK Észak-Dunántúli Osztály, Györ

Máthé M. (1995) Az Észak-Dunántúli Térség iparszerkezetének változása. In: Észak-Dunántúl területfejlesztési koncepciója. MTA RKK NYUTI. Györ

Máthé M. (1996) A konjunktúrakutatás módszerei és magyarországi gyakorlata. In: A regionális konjunktúrakutatás megalapozása. (Helyzetfeltáró tanulmány) MTA RKK NYUTI Közleményei 23. Györ

Máthé M. (1996) Az Európai Uniohoz való csatlakozás hatása az Északnyugat-Dunántúl ipari szerkezetének átalakulási folyamatára. In: Magyarország Európai Uniohoz csatlakozásának társadalmi-gazdasági kérdései, különös tekintettel Északnyugat-Dunántúlra. VEAB Tudományos Konferencia. Komárom 1996. 149-170. o.

Máthé M. (1996) Az ipari szerkezet átalakulása. Veszprém megyében és Veszprém városában. In: Veszprém megye területfejlesztési koncepciója. MTA RKK NYUTI, Györ

Máthé M. (1996) Nagyvállalatok szerepe Veszprém területfejlesztésében. (Veszprém megyében és Veszprém városában.) In: Veszprém megye és Veszprém város területfejlesztési koncepciója. MTA RKK NYUTl, Györ

Nemzeti Területfejlesztési Koncepció. Tervezet. Budapest. KTM. 1996. Kézirat.

Rechnitzer J.(1982) Területi szempontok az iparszerkezet átalakításához. Tér és Társadalom 1989/2. sz. 49-73. o.

Rechnitzer J. (1985) Ipar, épitőipar. Györi Tanulmányok 6. Györ 1985. Györ Megyei Város Tanácsa 1985. 26-40. o.

Tőrök Á. (1994) Gazdasági átalakulás és vállalati magatartás. Magyar Tudomány. 1994/11. sz. 13041309. 0 .

Török Á. (1995) Forgatókönyv a sikerröl és a kudarcról. Figyeló 1995. szeptember 7. 24-25. o.

Török Ȧ.-Zsarnay J. (1995) EU-iparpolitika és -versenypolitika: egymás helyettesitői vagy kiegészítöi? Külgazdaság 19-35. o.

Ványai J. (1995) Regionális politika és válságkezelés. In: Attekintés a magyar gazdaság strukturális folyamatairól. Résztanulmányok. MTA Ipar-és Vállalatgazdaság-Kutató Intézet, Budapest, 142-177. o.

Viszt E. (1994) A termelékenység és foglalkoztatás konfliktusai a gazdasági átmenet idején Magyarországon. Közgazdasági Szemle 1994/3. 254-267. o.

Viszt E. (1995) Külkereskedelmi prognózis. Kivihetô tervek. HVG 1995. május 27. I13-117. o.

Weyer B. (1995) Nyomdaipari vámverseny. Nyomás kifelé. HVG 1995. majjus 20. 124-126. o.

Zeitlin J. (1994) Ipari kőrzetek és regionális gazdasági megújulás. Közgazdasági Szemle 1994/1. 14-25, o. 


\title{
TRANSITION OF THE ECONOMIC AND INDUSTRIAL STRUCTURE OF NORTHWEST TRANSDANUBIA
}

\author{
MÁRIA MÁTHÉ
}

The study attempts to briefly analyse those groups of factors through which the transition process of the Hungarian economy and industry can be examined. As a result of this process, some initial phases of the core regions of the regional organisations, similar to the market economy districts of the developed countries, can be seen. In this process both local and regional governments and the State government played an important role. The process was extremely difficult, as practically the whole of this pioneer process took place without any prior experiences and samples. It went with only one deficiency, or "Scarlet Letter": It almost completely lacked Hungarian capital. Among the foreign investors there was a number of soldiers of fortune, and foreign capital which arrived with speculation purposes, which pollutes the environment and pays unfairly low wages still persists.

Given the experiences of the transformation process, we can clearly define those instruments - economic, regional and industrial development strategy of the government, regional influencing factors, e.g. large businesses, local and regional power - the knowledge of which is necessary for either the local or the regional level of administration to intervene in the development processes. Furthermore, we can also clearly define those endowments in the Nortwest Transdanubian region which can be the bases of an innovation-oriented regional economy that is built on economic clusters.

From the applied tools, the available state resources play an important role because the expectations of the State's will can be asserted through them, until a certain size of the businesses, of course.

As a summary we can say that the complex processes amounted to the strengthening and capital concentration of the foreign, private owned large businesses in Nortwest Transdanubia and maybe at Hungarian level too, at the same time several newly established small and medium size enterprises went bankrupt. However, if the drop in the foreign share in the capital assets is the consequence of the withdrawal of the speculation capital - i.e. the capital that is not integrated into the regional economy - from Hungary, then a positive process has started which will probably result in the appearance of industrial and economic districts which provide a stable living and development for the region. 